NBER WORKING PAPERS SERIES

MACROECONOMIC POLICY AND ELECTIONS IN OECD DEMOCRACIES

Alberto Alesina

Gerald D. Cohen

Nouriel Roubini

Working Paper No. 3830

NATIONAL BUREAU OF ECONOMIC RESEARCH

1050 Massachusetts Avenue

Cambridge, MA 02138

Sept ember 1991

May 1991; revised August 1991. Prepared for the Sapir Conference on "The Political Economy of Business Cycles and Growth, "Tel Aviv University, June 2-3, 1991. We would like to thank our discussants, Alex Cukierman and Ron Shachar, and several conference participants for very useful comments. Alesina's work was supported by a sloan Research Fellowship. This paper is part of NBER's research program in Financial Markets and Monetary Economics. Any opinions expressed are those of the authors and not those of the National Bureau of Economic Research. 


\title{
MACROECONOMIC POLICY AND ELECTIONS IN OECD DEMOCRACIES
}

\author{
ABSTRACT \\ The purpose of this paper is to test for evidence of \\ opportunistic "political business cycles" in a large sample of 18 \\ OECD economies. Our results can be summarized as follows: 1) we \\ find very little evidence of pre-electoral effects of economic \\ outcomes, in particular, on GDP growth and unemployment; 2) we \\ see some evidence of "political monetary cycles," that is, \\ expansionary monetary policy in election years: 3) we also \\ observe indications of "political budget cycles," or "loose" \\ fiscal policy prior to elections: 4) Inflation exhibits a post- \\ electoral jump, which could be explained by either the pre- \\ electoral "loose" monetary and fiscal policies and/or by an \\ opportunistic timing of increases in publicly controlled prices. \\ or indirect taxes. \\ Alberto Alesina \\ Department of Economics \\ Harvard University \\ Cambridge, MA 02138 \\ and NBER \\ and CEPR \\ Nouriel Roubini \\ Department of Economics \\ Box 1972 - Yale Station \\ Yale University \\ New Haven, CT 06520-1972 \\ and NBER \\ and CEPR \\ Gerald D. Cohen \\ Department of Economics \\ Harvard University \\ Cambridge, MA 02138
}




\section{Introduction}

Do politicians manipulate economic policy in order to win elections? For many economists, political scientists and laypeople, the answer to this question is obvious: of course they do! In a very influential paper, Nordhaus (1975) formalized and clarified the idea of an opportunistic "political business cycle." According to this model, politicians stimulate aggregate deniand before elections in order to create fast growth and reduce unemployment. The inflationary consequences of this policy are elininated by a post-electoral contraction.

Surprisingly, the empirical literature generated by the Nordhaus paper yielded, at best, mixed results. Partly as a reaction to these empirical rejections and partly in response to the "rational expectation" critique, in the late eighties a new generation of "rational political business cycles models" emerged. This line of research includes work by Cukierman and Meltzer (1987), Rogoff and Sibert (1988), and Rogoff (1990). These models have empirical implications which are somewhat different from those of Nordhaus' (1975) model.

The purpose of this paper is to examine in detail the evidence of "political business cycle" (PBC) models on a large sample of 18 OECD economies using both the Nordhaus model and the new "rational" models as a guide to our study. Our results can be summarized as follows:

1) We find very little evidence of pre-electoral effects on economic outcomes, in particular, on GDP growth and unemployment, as implied by the Nordhaus model.

2) We see some evidence of "political monetary cycles"; that is, expansionary monetary policy in elections years. 
3) We also observe indications of "political budget cycles," or "loose" fiscal policy prior to elections.

4) Inflation exhibits a post-electoral jump, which could be explained by either the preelectoral "loose" monetary and fiscal policies and/or by an opportunistic timing of increases in publicly controlled prices, or indirect taxes.

It should be emphasized that this evidence on monetary and fiscal policy is statistically significant, but not extremely strong. Our interpretation of these results is that pre-electoral manipulation of economic policy occurs frequently, but not always, and is constrained by the politicians' concem about their "reputation." These results support modelling efforts which emphasize the constraints imposed on policymakers by economic agents' and voters' rationality.

In this paper we do not consider the "partisan" model of political cycles (Hibbs (1977, 1987), Alt (1985), and Alesina (1987)) which emphasizes systematic differences in macroeconomic policymaking between the "unemployment averse" left and the "inflation averse" right. However, in concluding we offer a synthesis and discussion of the results of the present paper in light of previous research which has found strong support for the "partisan" model.

Our paper is organized as follows. In section 2 we briefly review the theory of opportunistic political business cycles. In section 3 we review previous empirical results. Section 4 describes our data. Section 5 explores the extent of "political business cycles" on growth and unemployment; this section extends earlier results by Alesina and Roubini (1990). Section 6 presents the results on inflation. Section 7 discusses the evidence for monetary policy. Section 8 considers fiscal policy nanely budget deficits, spending and taxes. The final section 
3

suggests an interpretation of our results in the broader context of the literature on political cycles.

2. The Theory of "Opportunistic Political Cycles"

The original model by Nordhaus (1975) is based upon the following assumptions:

(1) The economy can be described by an "expectations augmented"

Phillips curve.

(2) Expectations are adaptive.

(3) Politicians control a policy instrument which directly affects aggregate demand.

(4) Politicians are "opportunistic": they only care about holding office.

(5) Voters are naive and retrospective: they judge the incumbent government by evaluating positively high growth, low unemployment and low inflation. They heavily discount past observations, and do not understand the economic model which relates inflation and unemployment.

(6) The timing of elections is exogenously fixed.

Based upon these hypotheses Nordhaus obtains well-known empirical implications:

(a) every incumbent government expands the economy immediately before each election by taking advantage of the favorable short-run Phillips curve; (b) inflation increases around election time as a result of this expansion;' (c) inflation is reduced by a post-electoral contraction of 
aggregate demand which leads to a downturn or recession; (d) the economy exhibits an "inflation bias, "that is, inflation is higher than "socially optimum."

The present paper is concerned with the first three implications. In fact, although the experience of the past 25 years suggests that an inflation bias may indeed exist, other models are consistent with this observation. In particular an inflation bias is the central implication of the "time consistency" literature originated by Kydland and Prescott (1977) and Barro and Gordon $(1983 a, b)$.

\subsection{Rational Models}

The application of game theory to macroeconomics has led to a reformulation of the insight of the "political business cycle" model in a rational expectations framework. This result was originally achieved by Cukierman and Meltzer (1987), Rogoff and Sibert (1988), and Rogoff (1990). Persson and Tabellini (1991) later provided interesting extensions along the same lines. In these models, governments have the same utility function as private agents (i.e. they care about unemployment, inflation, and government spending in the same way as private agents do), but they are also "opportunistic." That is, governments care about winning elections, get welfare from being in power, and do not have "partisan" motivations. These papers share two basic ingredients: i) different governments are characterized by different degrees of competency; ii) the government is more informed than the voters about its own level of competency.

In Cukierman and Meltzer (1987), different governments are characterized by differing abilities to forecast. In Rogoff and Sibert (1988) and Rogoff (1990) "competency" is referred to as the government's efficiency in reducing "waste" in the budget process. That is, more 
competent governments can produce more public goods for given fiscal revenues. Persson and Tabellini (1991) apply Rogoff's "competency" model to the Phillips curve case; more competent governments can achieve higher growth with less unexpected inflation. In all of these models, the incumbent government has an incentive to "signal" its competence by engaging in preelectoral manipulations of policy instruments.

In the present paper we will focus specifically on the monetary and budget cycles studied by Rogoff and Sibert (1988) and Rogoff (1990). In the former paper, an equilibrium with signaling looks as follows: incumbents reduce taxes and/or increase spending before eloctions, to appear "competent" since, needless to say, voters prefer competent governments to less competent ones. Pre-eloctoral deficits are monetized, but the effects of monetization on inflation and on the seignorage tax are perceived by the voters only with a lag, thus after the eloction. Although voters are rational and aware of the policymakers' incentives, pre-electoral deficits for signaling purposes still occur. ${ }^{2}$

Rogoff (1990) presents a non-monetary model in which he focuses upon government spending on "consumption" (or transfers) and "investments." Signaling, in this model, takes the form of pre-electoral surges in immediately visible expenditures for "consumption" or transfers and cuts in "investment" expenditure. Although the decrease in investment is harmful for both productivity and efficiency, these results are observable ty voters only with lags. Thus, budget cycles take the form of distortions in the allocation of resources across public spending programs.

In summary, this body of research has made two important points: 
(a) "opportunistic" cycles survive in rational models, with substantially different features than the original Nordhaus formulation. In a rational model one is not likely to observe regular multi-year cycles on GDP or unemployment. ${ }^{3}$ Rational behavior of voters and economic agents would make these cycles impossible or counterproductive for the politicians. "Rational cycles" should thus take the form of short-run manipulations of policy instruments around elections. In other words, politicians may find it much easier and electorally rewarding to "mail some checks" before elections, print money, and postpone tax increases ("read my lips"), than to reduce the rate of unemployment in the election year.

(b) "retrospective voting" is not inconsistent with rational behavior, that is, it is a rational strategy for the voters to judge the incumbent's performance based upon pre-electoral economic conditions. This is, of course, a key element for the existence of opportunistic cycles.

Notice that, while the first implication concerning "signaling" crucially rests upon the assumption of asymmetric information over the government's competence, the second does not. In fact, one can observe rational retrospective voting even without asymmetric information, as long as competence is serially correlated (see Alesina, Londregan and Rosenthal (1991)). That is, rational retrospective voting emerges even in a model where the voters and the government have the same information about the government's competence, as long as the latter is serially correlated.

\section{Review of Previous Empirical Results}

Tests of opportunistic "political business cycles" can be divided into two categories: tests on policy outcomes, namely output growth, unemployment, and inflation, and tests on policy 
instruments such as money growth, taxes, transfers, and government spending. The first set of tests (on policy outcomes) in our view, overwhelningly rejects the "political business cycle" hypothesis. The second set of tests (on policy instruments) has yielded mixed results.

Soon after the publication of Nordhaus' (1975) paper, McCallum (1978) and Golden and Poterba (1980) rejected Nordhaus' model on economic outcones, using U.S. data. Paldam (1978) obtained similar negative results on a sample of OECD economies. Further rejection of the "political business cycle" model on GNP and unemployment in the U.S. were presented more recently by Hibbs (1987) and Alesina (1988). For a large sample of OECD economies similar rejections were obtained by Alesina (1989) and Alesina and Roubini (1990).

Haynes and Stone (1989) claim to have found support for the Nordhaus hypothesis on GNP in the U.S. However, in our view, a careful analysis of their results suggests that they have found evidence of "partisan" effects rather than of opportunistic cycles. The same criticism applies to results presented by Nordhaus (1989). For an exposition of this critical observation see Alesina's (1989) comment on Nordhaus. ${ }^{4}$

The evidence on manipulation of policy instruments is more favorable to the "political business cycle" model. Tufte (1978) presents evidence of manipulation of the timing of fiscal instruments, in particular transfers, and evidence of "monetary cycles." His evidence is, however, confined to a few American elections. Results in line with those of Tufte (1978) on fiscal transfers are also reported in Alesina (1988). Bizer and Durlauf (1990) report results on the dynamics of taxes in the U.S. which claim to support a political budget cycle. ${ }^{5}$ Both Tufte (1978) and Hibbs (1987) find evidence of political business cycles on disposable income. This 
observation, coupled with the lack of sinilar evidence on GNP, suggests the presence of "fiscal cycles."

Recently, McDonald (1991) has found evidence of public expenditure cycles by examining state level evidence in the U.S. Alesina (1989) presents some qualitative evidence which does not rule out the existence of "budget cycles" in OECD economies. This evidence is however weak and very far from conclusive. Finally, Grier $(1987,1989)$ reports interesting results which identify a monetary cycle in a sample from the early sixties to the very early eighties in the U.S. However when the sample is extended to include more of the eighties the results tend to vanish (see Grier (1989) and section 7 of the present paper).

4. Data

We consider all the OECD economies which have been democracies for the sample period which is, for most of our regressions, 1960 to 1987. The countries included in our study are Australia, Austria, Belgium, Canada, Denmark, Finland, France, Germany, Japan, Ireland, Italy, the Netherlands, New Zealand, Norway, Sweden, Switzerland, the United Kingdom and the United States. Our data set for output, GDP, unemployment and inflation is the same one used in Alesina and Roubini (1990). Inflation is defined as the yearly rate of change of CPI from IMF, IFS. Output growth is defined as the yearly rate of change of real GDP (or GNP) from IMF, IFS. Unemployment is oblained from OECD; we consider the total standardized unemployment rate. More details on country specific data issues can be found in Table A-1 of Alesina and Roubini (1990). Data for money supply are also obtained from IMF, IFS, with money growth defined as the yearly rate of change of MI. Our data for the fiscal variables used 
9

in section 8 are the same as those used by Roubini and Sachs (1989). Sources of election dates and of electoral results are Alt $(1985)$ and Banks $(1987,1989)$. The same data set for elections used in Alesina and Roubini (1990) is adopted here. See Table A-1 in the Appendix for a description of the political data.

5. Political Business Cycles on GDP and Unemployment

In this section we review and extend results obtained by Alesina and Roubini (1990).

A simple but powerful test of the PBC is obtained by running the following panel regression of time series cross section data, for instance on output growth:?

$$
y_{n}=\alpha_{0}+\alpha_{1} y_{i n-1}+\alpha_{2} y_{i-2} \ldots+\alpha_{n} y_{k-n}+\alpha_{n-1} y w_{k}+\alpha_{n-2} P B C_{k}+\varepsilon_{i k}
$$

where $y_{n}$ is the rate of output growth for country $i$ at time $t$; this rate of growth is defined as $y_{u}=\frac{x_{k}-x_{u-4}}{x_{u-4}} \cdot 100$ where $x_{i}$ is the level of real GDP in country $i$ at time t. $y w_{k i}$ is a proxy for the growth of the world economy; this proxy is obtained as the average growth of the seven largest economies in our sample, weighted by each country's share of GDP over the total.' PBC is a "dummy" which captures the dynamic implication of the theory. Several different definitions of the dummy are used. In addition, we introduce country dummies in the regressions, to correct for country specific effects. The autoregressive specification for the dependent variable is chosen as the "best" using standard techniques." 
Table 1 reports the results for two regressions on GDP growth, which differ in the specification of the political dummy. The two dummies, $P B C N$, with $N=4$ and $N=6$ reported in the first and second column respectively, are defined as follows:

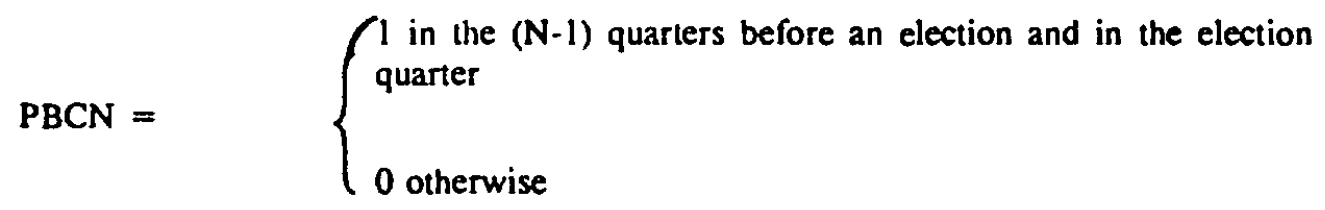

In the sample we have 144 elections. ${ }^{10}$ The country dummies are not reported, but were included in the regressions. In both regressions the political dummy, has the sign opposice from the theoretical prediction, although they are insignificantly different from zero.

Table 2 reports analogous results for unemployment. The dependent variable is $U^{\text {Dtr }}$, defined as the difference between the domestic unemployment rate and the proxy for the OECD unemployment rate, defined analogously to the world average GDP growth. In evaluating results on unemployment, one must be aware of problems of "unit roots," (see, for instance Blanchard and Summers (1986)). By taking the difference from the world average, rather than using levels as the dependent variable and the world average as a regressor, unit roots problems are somewhat, although far from completely, mitigated. In any event, the results of Table 2 are essentially identical as far as the political dummies are concerned, to those obtained by using the world average as a regressor. In Table 2 the cocfficients on PBC4 and PBC6 have the correct sign but they are insignificantly different from zero. 
Several different specifications of the regressions in these two tables were tried, also leading to no support for the theory. First we tried to hold "partisan effects" constant, by distinguishing (with appropriate dummies) "left" and "right" wing governments. As reported in Alesina and Roubini (1990), we found substantial evidence of partisan effects, but the PBCN dummies remained insignificant. Second, we ran the regressions without correcting for the "world variable." One may argue that voters are so naive that they do not account for the world economic cycle when they evaluate the state of their economy. Once again no evidence of "political business cycles" was found. All these results are not reported but are available upon request.

Tables 3 and 4 which are borrowed from Alesina and Roubini (1990) display country by country results on growth and unemployment respectively. In these tables, for each country we report the "best," in terms of the t-statistic of the coefficient on the PBCN dummy, of the two regression with PBC4 and PBC6. This procedure is, of course, very "generous" to the theory.

Not surprisingly, given our panel regressions, our country results are mixed at best. In the growth regressions in only four countries, that is; the U.K., Germany, New Zealand, and Japan, the coefficient has the sign predicted by the theory and is statistically significant (or borderline) at standard levels. The regressions on unemployment exhibit a majority of "correct" signs on the coefficient of the PBCN variable, but none of them is statistically significant. New Zealand is not included for lack of quarterly data on unemployment. 
6. Political Business Cycles on Inflation

According to Nordhaus' model, the counterpart of the pre-electoral expansion is a surge of inflation immediately before and/or after the election, depending on the exact specification of the lag structure in the Phillips clirve. The Rogoff and Sibert's (1988) budget cycle model has a similar implication for inflation, but no implications for growth and unemployment.

In Table 5 we display panel regressions on the inflation rate $(\pi)$ where the "world average," $\pi \mathrm{W}$, is obtained analogously to the world average growth. We present two regressions, one using $\mathrm{PBCX}$, and the second one with $\mathrm{PBC}$ which are defined as follows:

PBCX $=\left\{\begin{array}{l}1 \text { in the two quarters preceding and following an election, and } \\ \text { in the election quarter } \\ 0 \text { otherwise }\end{array}\right.$ $\hat{P B C 4}=\left\{\begin{array}{l}1 \text { in the three quarters following an election and in the election } \\ \text { quarter } \\ 0 \text { otherwise }\end{array}\right.$

Table 5, which extends earlier results by Alesina and Roubini (1990), shows that the dummy $\mathrm{PB} C 4$ has a very significant coefficient. On the other hand, the coefficient on PBCX is much smaller and not significant at the $5 \%$ confidence level. Further sensitivity analysis using various 
pre- and post-electoral dummies (available upon request) confirm that the surge in inflation is short-lived (lasts about a year) and isnmediately follows, rather than precedes, the election.

Table 6, reproduced from Alesina and Roubini (1990), reports country by country results on inflation using the dummy $\mathrm{PBC} 4$ which appears to be the most significant of the panel regressions. This table shows that in almost all of the countries the coefficient on PBC4 is positive, as predicted by the theory; in half of the countries the t-statistic on the coefficient is above one, and in Denmark, France, Germany, Italy, and New Zealand the coefficient is borderline significant at the ten percent level or better. Hence, the PBC effect on inflation, although not very strong in any country is rather widespread across countries, and therefore appears in the panel results quite strongly.

The evidence presented in the past two sections, viewed together can now be summarized as follows:

(1) Two countries, Germany and New Zealand, show effects on both a "real" variable, GDP growth, and inflation which are consistent with the Nordhaus model. One other country, Japan, exhibits borderline results, particularly on inflation." All of the other countries show either no evidence of cycles or evidence for only one of the two variables.

(2) There seems to be a much more widespread electoral cycle on inflation than on growth and unemployment. This finding is inconsistent with the Nordhaus model, but it is consistent with models which emphasize cycles on policy instruments.

The finding that Germany has political business cycles is somewhat surprising, given the fact that the Bundesbank is one of the most, if not "the" most, independent Central Bank in the world. 
In the next two sections we look directly at evidence on policy instruments.

\section{Monetary Policy and Elections}

If one expects to obserye some type of electoral business cycle, then one should detect electoral manipulation of either, or both, of the macroeconomic policy instruments; monetary and fiscal policy. The focus of this section is to analyze the implications of the opportunistic "political business cycle" on monetary policy. Before undertaking this task we must be careful to note, as discussed earlier, that politicians of different countries may be severely constrained in their monetary policy manipulation by the autonomy of the central bank.

Given this forewarning, we can now proceed with our findings. Our tests adopt methodology analogous to the output, unemployment and inflation regressions used by Alesina and Roubini (1990), which were extended earlier in this paper. A similar technique was also used by Grier $(1987,1989)$ for the United States.

The procedure used to test the PBC for both the pooled cross-section time-series regressions, as well as the country by country regressions, was as follows:

$$
m_{i s}=\beta_{0}+\beta_{1} m_{i t-1}+\beta_{2} m_{i t-2}+\ldots+\beta_{n} m_{i t-n}+\beta_{n+1} P B C N_{i t}+\varepsilon_{t}
$$

where $m_{i t}$ is the rate of growth of money for country $i$ at time t. PBCN $N_{i t}$ is the electoral "dummy" variable discussed earlier, which takes on a positive value the last three, or five quarters before the election, and during the quarter of the election. The PBC theory implies that the coefficient on $\mathrm{PBCN}_{\mathrm{it}}$ should be positive and significantly different from zero, indicating that money growth is higher immediately before an election. Our sample of quarterly data includes all the 18 countries listed above, and the sample period is $1958-1987 .{ }^{12}$ 
Money growth is defined as the yearly rate of change of MI. This definition is used to remove seasonality from the money data. Tests with the quarterly rate of change of $\mathrm{Ml}$, as well as other methods of seasonally adjusting the data reveal no change in the results. The autoregressive specification for the dependent variable is chosen as the "best" using standard techniques. This is found to be an AR(9); however, the results are not dependent on the lag specification of the model. For brevity, the coefficients on the lags are not displayed.

The top of Table 7 labelled "PBC Test" reports the results of the panel regressions for PBC4 and PBC6. The table, which includes specifications with and without country dummies (for conciseness the coefficients on these dummies are not reported), indicates that the coefficient on the electoral dummy is both the correct sign, and significantly different from zero. This outcome supports the implications of the PBC model. Thus, ceteris paribus, money growth is higher for the year, to year and a half, before an election. All of the reported results were found to be invariant to tests of robustness such as leading or lagging the political dummy, or excluding individual countries which might be believed to be driving the results. In addition, including a world average money growth variable, obtained analogously to the world average output growth, did not change the results. ${ }^{13}$ Tests employing Grier's sinusoidal electoral dummy yielded no change in the results. It was felt that this symmetric $V$-shaped variable which has it maximum value the period of the election, declines until the midpoint between elections (when it reaches its minimum), and then increases until the election, constrained the dynamic implications of the theory, and thus the PBCN political dummy was the preferred variable.

The country by country results reported in Table 8 are not as compelling. Although, for PBC4, a vast majority of the countries in the sample (13 out of 18 ) have a coefficient greater 
than zero, we cannot reject the hypothesis that the coefficient is positive and significantly different from zero (at the $5 \%$ level) for only 2 countries, Australia and New Zealand. In addition, we cannot reject for Germany at the $10 \%$ level, and three other countries have a tstatistic greater than one.

It is not surprising that New Zealand, which until recently had one of the least autonomous central banks (see Alesina (1989) and Grilli, Masciandaro and Tabellini (1991)), shows the most significant evidence of an electoral cycle. Conversely, it is quite surprising that Germany, with one of the most independent central banks, displays some form of political manipulation of its monetary policy. Finally, our results for the United States differ from those of Grier $(1987,1989)$. However, further study of this matter reconciles these differences. If we split our sample in the early eighties, we discover that Grier's findings of an opportunistic PBC in the US does in fact hold for his sample period of the early sixties to the early eighties. After the early eighties, the model does not perform as well. One explanation may be that policy manipulation was ineffectual, and thus not utilized after 1980 due to the well documented instability of the money demand equation in the United States. ${ }^{14}$

We can also note that for both the panel and the country by country data sets the outcomes of the PBC6 regressions are weaker. This result may be explained as follows. Opportunistic PBC models indicate that the office holder wishes to pump up the economy right before the election, without any concurrent inflation. Given the long run inflationary implication of monetary policy, expansionary monetary policy too far in advance will result in an a boom too early, and high levels of inflation before the election. 
We also investigated a "partisan/opportunistic" interaction term. As emphasized by Lindbeck (1976) and Alesina (1989), pre-electoral opportunistic behavior for left wing governments may be different than that of right wing governments. More specifically, left wing governments, who at the beginning of their administration pursued expansionary monetary policies to lower unemployment, may be reducing money growth at the end of their terms, to bring down the inflation caused by their initial policies. An "opportunistic" left wing government may want to emphasize their anti-inflation policies to appeal to the "median voter" in election years. Conversely, right wing governments, who undertook contractionary monetary policy to lower inflation, may be expanding money at the end of their administrations to enter elections during a period of expansion.

A formal test of this hypothesis can made by running the following panel and country by country regressions:

$$
\begin{aligned}
m_{i j}=\gamma_{0}+ & \gamma_{1} m_{u-1}+\gamma_{2} m_{i-2}+\ldots+\gamma_{n} m_{i-n}+ \\
& \gamma_{n+1} D U M L_{i u}+\gamma_{n+2} P B C N L_{i j}+\gamma_{n+3} P B C N R_{i t}+\varepsilon_{i}
\end{aligned}
$$

DUML $L_{i}$ is a dummy which identifies left wing governments, and $P B C N L_{i k}$ and $P B C N R_{i}$ are interaction terms between $\mathrm{PBCN}$ and the left and right wing government dummies respectively. Is If "partisan/opportunistic" political manipulation of monetary policy exists, one expects the coefficients on the left and right wing interaction terms to be different. The strong form of this theory, as described above, suggests that the coefficients should in fact be of opposite sign.

The bottom of Table 7 labelled "Partisan Test" reports the results for the panel regressions. For PBC4, we find that the coefficient for right wing governments is significantly 
different from zero at the $5 \%$ level, while that of left wing governments is not. However, we cannot reject the hypothesis that they are of the same magnitude. This test, which has the correct negative sign, is displayed in Table 7 as "Difference Test4."

The panel results for PBC6 are less compelling. We find that the coefficients for both left and right wing governments are not significantly different from zero. In addition, the difference test has the incorrect sign. This again may be attributed to the longer length of the political dummy, which is picking up more than just the pre-electoral dynamics.

Thus, for the country by country regressions, we present only the outcomes of the PBC4 regressions, which can be found in Table 9. ${ }^{16}$ These results indicate that only 9 out of 15 countries exhibit the expected negative sign for the difference test. ${ }^{17}$ Some of the countries with the "incorrect" sign possess difference tests that are nearly significant.

In the sample of countries that exhibit the expected behavior, three, Austria, New Zealand, and Norway cannot reject the hypothesis, that their political parties pursue different monetary policies before elections, at the $5 \%$ level. In addition, two countries, France and Italy have t-statistics for the difference test less that minus one. Finally, for Australia and Germany we cannot reject the hypothesis that the coefficient on right wing governments is positive and significantly different from zero (at the $5 \%$ and $10 \%$ level respectively). While we can reject the same hypothesis for their left wing governments.

Thus, the results of the "partisan/opportunistic" tests are somewhat ambiguous, however, they do move in the expected direction. For the PBC model the pooled time-series cross-section results are more compelling than the country by country results indicating that political monetary cycles occur frequently but not systematically. 
8. Fiscal Policy, Budget Deficits and Elections

In this section we will consider the effects of elections on fiscal policy. Both traditional and recent "rational" PBC models imply that we should observe fiscal deficits before elections. However, these theories are vague about whether the pre-electoral fiscal expansion will occur through a reduction in taxes, or an increase in government spending or both. In principle, the actual combination of pre-electoral tax cuts and fiscal spending increases might change over time and across countries. We therefore start our analysis of pre-electoral budget cycles by concentrating on the fiscal deficits of the public sector.

In analyzing the effects of elections on fiscal deficits, one needs a structural model of budget deficits in order to control for the economic determinants of budget deficits. We rely upon the structural model of budget deficits used by Roubini and Sachs (1989) to study the effects of political instability on budget deficits. The data sample available for this section of the paper is smaller than the one used above. The size of the sample is limited by the availability of consistent OECD data on public debt (see Roubini and Sachs (1989)). The countries (and sample periods) included are as follows: Austria (1970-1985), Belgium (19601985), Canada (1961-1985), Denmark (1971-1985), France (1960-1985), Finland (1970-1985), Germany (1960-1985), Italy (1964-1985), the Netherlands (1970-1985), Norway (1970-1985), Sweden (1970-1985), the United Kingdom (1960-1985), and the United States (1960-1985).

The specification of our model is consistent both with elements of optimizing approaches to fiscal deficits (such as the "tax smoothing" model of Barro $(1979,1986)$ ) and with traditional Keynesian models of fiscal deficits. In fact, both theories imply that fiscal deficits are countercyclical: i.e. fiscal deficits will emerge during periods of recession and growth 
slowdown. In the tax-smoothing approach, recessions lead to fiscal deficits as optimizing governments try to minimize the deadweight losses from distortionary taxation; since they will stabilize tax rates, a recession will lead to a reduction of the tax base and a shortfall in revenues. Similarly, transitory shocks to government spending should also be financed through budget deficits.

In this sense, the sudden and sharp increase in budget deficits after 1973 in many OECD countries can be linked directly to the sudden slowdown in OECD growth and the corresponding sudden rise in unemployment after 1973. These shocks reduced revenues and increased government spending on what appeared to be a cyclical basis. Since it was widely expected then that the growth slowdown and the rise in unemployment would have been transitory, these deficits in the mid-seventies could have been consistent with the tax-smoothing equilibrium view. ${ }^{18}$

In addition to the tax smoothing hypothesis, the tendency towards deficits after a slowdown in growth, is exacerbated for two additional seasons. First, many major areas of public spending (e.g. unemployment compensation, social welfare expenditure, early retirement benefits, job retraining, and subsidies for ailing firms) are inherently countercyclical, so that portions of government spending actually tend to rise automatically when growth slows down and unemployment increases. The second reason is the intentional implementation in some countries of Keynesian aggregate demand policies in the face of a growth slowdown. The equilibrium model explicitly rejects the links of spending or taxes to the level of output and employment via aggregate demand, but many governments believed (and many still do so) in 
these links. Right or wrong, many governments reduce taxes or increase government spending during recessions.

In considering the economic determinants of budget deficits one should also include the effects of real interest rate shocks. For example, after 1979 the increase in world real interest rates, significantly and unexpectedly raised most governments' costs of debt servicing. One useful measure of the budgetary costs of higher interest rates is given by the debt to GDP ratio multiplied by the change in the differential between real interest rates and growth rates. Between 1979 and 1981, this measure rose by several percent of GDP in most of the industrial economies, thereby greatly adding to the fiscal burden. ${ }^{19}$

Given the above discussion of the determinants of fiscal deficits, as in Roubini and Sachs (1989), we estimate a pooled cross-section time-series regression where the left-hand side variable is the annual deficit, measured as the change in the debt-GDP ratio, $d\left(b_{k}\right)$. The basic explanatory variables are: $(1)$ the lagged deficit, $d\left(b_{n-1}\right) ;(2)$ the change in the unemployment rate, $d\left(U_{i}\right) ;(3)$ the change in the GDP growth rate, denoted $d\left(y_{i}\right) ;(4)$ the change in the real interest rate minus the growth rate, multiplied by the lagged debt-GDP ratio, $d\left(r_{1}-n_{2}\right)^{*} b_{i \cdot 1}$; (5) a dummy for political instability, $\mathrm{POL}_{\text {in }}$ first used in Roubini and Sachs (1989) (and to be described below); (6) an electoral dummy ELE $_{i}$ to be defined below; and (7) an error term, $v_{i n}$. The basic structure of the pooled regression model is the following ( $i$ denotes country, $t$ denotes time, and $d(x)$ denotes the change in variable $x)$ :

$$
d\left(b_{i j}\right)=\delta_{0}+\delta_{1} d\left(b_{i-1}\right)+\delta_{2} d\left(U_{i j}\right)+\delta_{3} d\left(y_{i j}\right)+\delta_{4} d\left(r_{1}-n_{1}\right) b_{i-1}+\delta_{5} P O L_{i u}+\delta_{6} E L E_{u}+v_{i u}
$$

According to our discussion, we expect the following: $0<\delta_{1}<1$ (to allow for any slow adjustment and persistence of budget deficits); $\delta_{2}>0$ (since a rise in the unemployment 
rate raises government spending above its permanent value in the short term); $\delta_{3}<0$ (since a rise in GDP growth lowers government spending below its permanent value in the short term and may raise tax revenues); and $\delta_{4}>0$ (since a rise in $r-n$ directly raises $(r-n) b_{i-1}$, which if transitory should be accommodated by a temporary rise in the budget deficit).

Before introducing and discussing the political and electoral determinants of budget deficits, in column 1 of Table 10 we present the results of the regression when we include only the economic variables. This specification provides a rather successful account of the role of economic shocks in inducing budget deficits in the industrial countries. In particular, a rise in unemployment (denoted by DUB) raises the budget deficit; a rise in the debt-servicing cost (denoted by DRB) raises the budget deficit; and an acceleration of GDP growth (denoted by DGR) lowers the budget deficit, indicating that the deceleration of GDP growth after 1973 contributed to the rise in budget deficits. Note that the variable measuring this slowdown in growth is highly significant. ${ }^{20}$ Finally, the lagged deficit (DBYL) enters with a coefficient of about 0.70 , suggesting that about 70 percent of the lagged budget deficit persists to the next period.

In order to test the hypothesis that governments manipulate fiscal policies before elections in order to maximize their reelection probabilities, in column (2) we add to the basic regression a dummy ELE that takes value 1 in election years and zero otherwise. In constructing the variable ELE we need to consider that, since our data on deficits are on a yearly basis, the exact time of an election during a year might be important for assessing the effects of elections on fiscal deficits. More specifically, if an election occurs lowards the end of the year $t$, we can expect that an opportunistic government would run a fiscal deficit during that year. However, 
if the election occurs towards the beginning of year $t$, it is more reasonable to assume that the fiscal expansion will occur in year $t-1$ so as to be timed with the early election time in year $t$. In practice, in constructing the variable ELE we assign value 1 to the dummy in the pre-electoral year $t-1$ if the election will occur in the first and second quarters of year $t$; while we assign value $t$ in the electoral year $t$ if the election occurs in the third or fourth quarter of year $t$. As an additional check on the model we also run regressions using a slightly different electoral dummy (ELX instead of ELE). ELX takes the value 1 in the election year regardless of whether the election occurs in the first or second half of the year.

In addition to the electoral variable we also add to the regression the political variable successfully used by Roubini and Sachs (1989) to study the effect of government fragmentation on budget deficits. The hypothesis in that paper was that multi-party coalition governments, especially those with a short expected tenure, are poor at reducing budget deficits. ${ }^{21}$ We therefore add to the regression the Roubini-Sachs index (denoted POL for country $i$ at time $t$ ) which measures the degree of political cohesion of the national government. The index is constructed as follows ${ }^{2}$ :

\footnotetext{
$\mathrm{POL}=\left\{\begin{array}{l}0 \begin{array}{l}\text { one-party majority parliamentary government; or a presidential } \\ \text { government, with the same party in the majority in the executive } \\ \text { and legislative branches }\end{array} \\ 1 \begin{array}{l}\text { coalition parliamentary government with } 2 \text { coalition partners; or } \\ \text { presidential government, with different parties in control of the } \\ \text { executive and legislative branches }\end{array} \\ 2 \begin{array}{l}\text { coalition parliamentary government with } 3 \text { or more coalition } \\ \text { partners }\end{array} \\ 3 \text { minority parliamentary government }\end{array}\right.$
} 
The results of the estimations are shown in columns (2) - (4) in Table 10. Several different versions of the regression are shown, involving different ways of including the variables ELE and POL, either jointly or separately. In column (2), we introduce the political instability variable and, as in Roubini and Sachs (1989), we find that (after controlling for the economic determinants of deficits) a greater degree of political instability (as proxied by the index POL) leads to higher budget dcficits. ${ }^{23}$ In column (3), we add our electoral dummy ELE to the regressors used in column (2); we find that, after controlling for the economic determinants, both POL and the electoral dummy, ELE, have the right sign and are statistically significant at the $5 \%$ confidence level. In other words, real fiscal deficits are higher in the year leading to an election. In column (4), we drop the POL variable and consider the effect of ELE alone; we again find a statistically significant coefficient.

The effect of elections on budget deficits is significant both statistically and economically; the estimated coefficient on ELE in column (3) and (4) implies, that after controlling for other determinants of fiscal balances, real fiscal deficits will be higher in election years by more than 0.6 percent of GDP. We also ran the panel regressions in Table 10 using the electoral dummy ELX instead of ELE (ELX takes the value 1 in the election year regardless of whether the election occurs in the first half of the year or the second half). As expected, ELX works less well than ELE, since this dummy variable does not correspond to the timing of elections. However, in these regressions ELX has the right sign and is statistically significant at the $10 \%$ confidence level. These results are available upon request.

In column (5), we investigate an interaction term of the electoral variable with the lagged deficit (termed DBYLELE), with the view that the speed of adjustment to an inherited level of 
the deficit, $d\left(b_{k-1}\right)$ might be lower in election years. When we introduce the interaction variable DBYLELE in column (5), we find that the sign is the expected positive one (deficits are more persistent in election years, i.e. the fiscal adjustment to past deficits is slower during election periods) but it is only borderline significant (the t-statistic is equal to 1.55).

The results in Table 10 provide some evidence that during an election year fiscal policy is "loose." It would be interesting to investigate which countries exhibit more pronounced electoral budget cycles. However, such a test difficult for two reasons: first, since the OECD data on public debt (from which we derived the real deficits measures) are available only on a yearly basis, the sample period for each country is quite small (ranging from 22 data points for the United States to 14 for Denmark); second, elections are infrequent events, and the data set for each country does not include more than four electoral observations. These small sample problems severely constrain the possibility of running meaningful country by country regressions. Keeping in mind the above important caveats and limitations, we ran the basic deficit equation for each country separately. We found the coefficient on the electoral dummy to be of the right sign in eight countries (Germany, Belgium, Japan, Austria, Netherlands, Norway, Finland, Denmark) but statistically significant (at the $10 \%$ confidence level) in only one (the Netherlands). ${ }^{24}$ While the above sample period constraints might account for these weak results, the inability to find strong electoral effects at the country level would suggest caution in arguing for a strong electoral budget cycle effect in this OECD sample.

Now that we have established some evidence in favor of fiscal manipulation, we can ask: does the electoral budget cycle found in the results displayed in Table 10 derive from increased spending before elections or reduced taxes? The available theoretical models of electoral budget 
cycles do not provide a clear answer to such a question. Empirically, the issue is ambiguous as well. First, the choice of whether to reduce taxes or increase spending in any single country may vary over time and over different elections. Second, different countries may differ in the way they expand fiscal policy before elections: some may reduce taxes and others increase spending. Given the above observations, we do not necessarily expect to find a strong effect of elections on government spending or taxes in a large panel of countries.

Despite these caveats, we attempted to test whether there are any electoral cycles in government spending or revenues, but found, little evidence of any effects. ${ }^{25}$ These outcomes are consistent with our prior that results of this kind are difficult to detect. We therefore leave attempts to systematically test whether particular sub-components of spending andlor revenues have more pronounced electoral cycles, to future research.

\section{Discussion and Conclusions}

The results of this paper, viewed in the context of the literature on political cycles, suggest some general conclusions. Previous empirical findings suggest that partisan effects on both policy instruments and economic outcomes are quite widespread in OECD economies. ${ }^{26}$ In particular, left wing governments, when elected, favor expansionary demand policies leading to a temporary increase in growth and reduction in unemployment. These policies lead to an acceleration in inflation which often persists (because of "credibility" problems) even after the initial real expansion has disappeared. According to this view, left wing governments often face new elections in a situation of high inflation; in this case, any further attempt to expand, as predicted by the Nordhaus model, would be counterproductive. In fact, the left may need to 
signal its competence in dealing with inflation by pursuing a "cautious" monetary policy. Conversely, when right wing governments are appointed, they are willing to incur the costs of an immediate recessions or downturns, in order to reduce inflation. After the initial downturn, the economy returns to its natural level of activity and inflation remains low. Thus, when the next election approaches, right wing governments have "room" to pursue expansionary policies, yielding a Nordhaus type political business cycle.

In addition to having these "partisan goals, " politicians are "opportunistic." That is, they prefer being in office rather than out. In addition, "partisan goals" can be implemented only if, first, elections are won. Thus, even partisan politicians, regardless of their ideology, may engage in opportunistic behavior if, by doing so, they can increase their chances of reelection (see Nordhaus (1989)).

Our results of the panel regressions are quite suggestive (we tend to emphasize these panel regressions above the country by country regressions because the former are not affected by the very common problem in this literature of scarcity of degrees of freedom). The panel results reject the Nordhaus formulation of the PBC but do not reject the "rational political budget cycles" of Rogoff and Sibert (1988). In fact, even though at the panel level we found no evidence of cycles on GDP and unemployment, we observed evidence of electoral cycles on monetary and fiscal policy instruments and on inflation. This result is consistent with the notion that it is easy to manipulate policy instruments, while it is more difficult to control policy outcomes. $^{27}$ The country by country results suggest however, that although these cycles are not strong in any particular country, they occur at least occasionally in many of the OECD democracies. 
Our interpretation of these results is that, in general, politicians try to avoid restrictive monetary and fiscal policies in election years and occasionally they are openly expansionary. This view is consistent with the overall significance of the electoral dummy in the full sample of countries, and with its lack of significance in many subsamples (i.e., specific countries). In summary, our results suggest that monetary and budget cycles occur frequently, and in several countries, but in no country (with the possible exception of New Zealand) do they occur in every election, and are they of very large dimensions.

Only two countries, Germany and New Zealand do not reject the Nordhaus model. The findings for Germany are somewhat surprising. This is the country with the most independent Central Bank, thus one would expect very little pre-electoral manipulation of monetary policy. One possible explanation of these somewhat puzzling results is Germany's ability to take advantage of its favorable short term unemployment/inflation tradeoff. Due to its strong commitment to price stability, yielding a flat short run Phillips Curve, one would expect even small manipulations of monetary policy to have large effects on outcomes. ${ }^{28}$ The case of New Zealand is much more convincing. The recent institutional reform in this country which significantly increased the degree of independence of the Central Bank may have been a step taken to limit electoral manipulation of monetary policy.

In our view, the results of the present paper are supportive of the "rational" approach to modelling political cycles. In fact, if voters were very naive, and politicians could manipulate the economy very easily, one should observe pre-electoral manipulations of instruments and outcomes which are much more widespread, easily detectable, and larger in magnitude than our findings suggest. Instead, we ascertain that fiscal and monetary cycles probably occur 
frequently, but not in every election and are of relatively moderate intensity. II would be quite interesting to pursue this analysis further to study when one is nore likely to observe opportunistic manipulations of policy instruments. Perhaps, they tend to occur when incumbents are unsure of reappointment and need an extra electoral boost, as suggested by Frey and Schneider (1978). Conversely, political cycles may not be observed when incumbents are "safe," and do not need to engage in any signaling of competence. 


\section{Notes}

1. In Nordhaus' (1975) original model inflation was supposed to begin to increase before the election. However by an appropriate choice of the lag structure in the Phillips curve one can build a model in which inflation increases after the election, without affecting the basic results (see Lindbeck (1976)).

2. To be precise, in Rogoff and Sibert (1988) the budget is always balanced, in the sense that the difference between spending and taxes is covered by seignorage.

3. Electoral cycles are not regular for several reasons. First, in a separating equilibrium only competent governments would try to signal their competence by expanding output before elections. Second, pooling equilibria in which both competent and incompetent governments follow the same policy are possible; in this case regular electoral cycles would again be less likely. (See Persson and Tabellini (1991) for more on this point.)

4. In a nutshell the point is the following. The "partisan theory" with rational expectations in a wage-contracts model as originally formulated in Alesina (1987) implies that at the beginning of a right wing government (i.e., Republican administration in the U.S), one should observe a downturn or recession due to an anti-inflationary policy. Later in their term of office, the economy recovers and returns to its "natural" level of economic activity. The opposite pattern is followed by democratic administrations. Thus, the empirical implications of the Nordhaus model and of this "partisan" model are similar for right wing governments, but opposite for left wing governments. Both Haynes and Stone (1989) and Nordhaus (1989) find "evidence" of 
political business cycles only for Republican administrations which suggests that, in fact they are not rejecting a "partisan" model.

5. However, a careful examination of their results suggest that their time dummies are significant in the second and third years of an administration. Conversely, an electoral dummy assuming the value of one in the two years preceding each election is insignificant.

6. See Roubini and Sachs (1989), Tables 3 and 4 and their data Appendix for more information.

7. See Alesina and Roubini (1990) for a discussion of this econometric approach.

8. The seven largest countries are (in 1987 order) U.S., Japan, Germany, France, the U.K., Italy, and Canada. An analogous definition is used to construct proxies for OECD unemployment, inflation, and money growth.

9. See Alesina and Roubini (1990) for further discussions of this fixed effect model.

10. We have adopted the convention of excluding elections which were held less than eight quarters after the preceding one. This convention eliminates cases in which very early elections were called to solve deadlocks caused by lack of a clear majority in the legislature resulting from the previous balloting.

11. Ito $(1990 \mathrm{a}, \mathrm{b})$ finds evidence of a strategic choice of election timing in Japan. Early elections tend to be called when the economy is doing well. Alesina and Roubini (1990) confirm this result for Japan.

12. There are two exceptions: because of data problems the sample for Canada is 1969.1 to 1987.4 and for Sweden is 1961.1 to 1987.3.

13. These results are available upon request.

14. See Friedman and Kuttner (1989) for an in depth discussion of the instability of the money 
demand equation in the 1980's. Also, Grier (1989) notes, in a footnote, this difference between pre- and post-1980 results of the political monetary cycle.

15. This was found to be the correct specification of the model after estimating the equations on the left and right wing governments separately. The coefficients on the lag money growth variables were found to be virtually identical.

16. The results for PBC6, which are similar to those of PBC4, are available upon request.

17. During our sample period, no left wing governments held power in Switzerland and Japan. For Canada, its smaller sample and our convention of excluding elections that were held less than eight quarters after the preceding one, required its exclusion from the sample.

18. By the early 1980's, however, it had become clear that the shocks had considerable persistence (to the point of spawning the new "hysteresis" theory of unemployment), and many governments began reducing their budget deficits. In broad terms, the equilibrium approach is much less successful in accounting for the persistence of budget deficits throughout the 1980 s in many OECD countries. See Roubini and Sachs (1989) for more tests on the equilibrium approach to fiscal policy.

19. This rise was particularly large, of course, in countries such as Belgium, Ireland, and Italy, which had already accumulated a large stock of debt. As with the unemployment increase and the growth slowdown, the effects of higher interest rates have turned out to be more persistent than many policymakers expected in the early 1980 s.

20. Its magnitude suggests that each 1 percentage point slowdown in GDP growth initially raises the budget deficit relative to GDP by 0.45 percentage points. 
21. See Alesina and Tabellini (1990) and Tabellini and Alesina (1990) for a formal model of the effects of political instability and conflict on budget deficits.

22. Details on the construction of the index for each particular country can be found in the text and data appendix of Roubini and Sachs (1989).

23. The magnitude of the coefficient on the POL variable, 0.004 , signifies that the difference ceteris paribus between a majority government and a minority government $(p=0$ versus $p=3$ ), is 0.012 , or 1.2 percentage points of added budget deficit per year.

24. These results are available upon request.

25. These results are available upon request.

26. See Hibbs (1977), Alt (1985), Alesina (1989), Paldam (1989a,b), and Alesina and Roubini (1990).

27. This finding that the $\mathrm{PBC}$ instruments have little influence on the real variables while inflation is strongly affected is also consistent with theories of the "dynamic inconsistency of monetary policy." (See Barro and Gordon (1983a), and Persson and Tabellini (1991) for surveys of this subject.)

28. We are grateful to Alex Cukjerman for suggesting this point. (See Lucas (1973) for morc on this subject.) 


\section{References}

Alesina, Alberto. 1989. Politics and Business Cycles in Industrial Democracies. Economic Policy 8: 55-98.

MA: M.I.T. Press. 13-52.

1988. Macroeconomics and Politics. NBER Macroeconomic Annual. Cambridge, 1987. Macroeconomic Policy in a Two-Party System as a Repeated Game. Quarterly Journal of Economics 102: 651-678.

, Londregan, John. and Rosenthal, Howard. 1990. A Political-Economy Model of the United States. NBER Working Paper no. 3611.

and Rosenthal, Howard. 1989. Ideological Cycles in Congressional Elections and the Macroeconomy. American Political Science Review 83: 373-398.

and Roubini, Nouriel. 1990. Political Business Cycles in OECD Economies. NBER Working Paper no. 3478.

and Summers, Lawrence. 1990. Central Bank Independence and Macroeconomic

Performance: Some Comparative Evidence. unpublished.

and Tabellini, Guido. 1990. A Political Theory of Fiscal Deficits and Government Debt in a Democracy. The Review of Economic Studies 57: 403-414.

Alt, James. 1985. Political Parties, World Demand, and Unemployment: Domestic and International Sources of Economic Activity. American Political Science Review 79: 1016-1040.

Banks, Arthur 1987,1989. Political Handbook of the World. State University of New York at Binghamton: CSA Publications.

Barro, Robert and Gordon, David. 1983a. Rules, Discretion, and Reputation in a Model of Monetary Policy. Journal of Monetary Economics 12: 101-122.

and 1983b. A Positive Theory of Monetary Policy in a Natural Rate Model. Journal of Political Economy 31: 589-610.

Bizer, David S., and Durlauf, Steven N. 1990. Testing the Positive Theory of Government Finance. Journal of Monetary Economics 26: 123-141.

Blanchard, Olivier and Summers, Lawrence. 1986. Hysteresis and the European Unemployment Problem. NBER Macroeconomic Annual. Cambridge, MA: M.I.T. Press. 15-78. 
Friedman, Benjamin M. and Kuttner, Kenneth N. 1989. Money Income and Prices After the 1980s. NBER Working Paper no. 2852.

Frey, Bruno and Schneider, Frederich. 1978. An Empirical Study of Politico-Economic Interaction in the United States. The Review of Economics and Statistics 60: 174-183.

Grier, Kevin B. 1987. Presidential Elections and Federal Reserve Policy: An Empirical Test. Southern Economic Journal 54: 475-486.

1989. On the Existence of a Political Monetary Cycle. American Journal of Political Science 33: $376-389$.

Grilli, Vittorio, Masciandaro, Donato, and Tabellini, Guido. 1991. Political and Monetary Institutions and Public Finance Policies in the Industrial Democracies. Economic Policy. forthcoming.

Hibbs, Douglas. 1977. Political Parties and Macroeconomic Policy. The American Political Science Review 71: 1467-1487.

1987. The American Political Economy. Cambridge, MA: Harvard University

Press.

Ito, Takatoshi. 1990a. The Timing of Elections and Political Business Cycles in Japan. Journal of Asian Economics 1: 135-146.

1990b. International Impacts on Domestic Political Economy: A Case of Japanese General Elections. unpublished.

Kydland, Finn and Prescott, Edward. 1977. Rules Rather Than Discretion: The Inconsistency of Optimal Plans. Journal of Political Economy 85: 473-490.

Lindbeck, Assar. 1976. Stabilization Policies in Open Economies with Endogenous Politicians. American Economic Review Papers and Proceedings: 1-19.

Lucas, Robert E. 1973. Some International Evidence on Output-Inflation Tradeoffs. American Economic Review 63: 326-334.

McCallum, Bennett. 1978. The Political Business Cycle: An Empirical Test. Southern Economic Journal 44: 504-515.

McDonald, Matthew. 1991. Political Budget Cycles: Evidence from the States. Harvard University Senior Thesis. 
Nordhaus, William. 1989. Alternative Models to Political Business Cycles. Brookings Papers on Economic Activity No. 2.

1975. The Political Business Cycle. Review of Economic Srindies 42: 169-190.

Paldam, Martin. 1989a. Politics Matter After All: Testing Alesina's Theory of RE Partisan Cycles. Aarhus University Working Paper.

1989b. Politics Matter After All: Testing Hibbs' Theory of Partisan Cycles. Aarhus University Working Paper.

1979. Is There An Electoral Cycle? Scandinavian Journal of Economics 81: 323 -

342.

Persson, Torsten and Tabellini, Guido. 1991 Macroeconomic Policy, Credibility and Politics. New York, NY: Harwood Academic Publishers.

Rogoff, Kenneth. 1990. Equilibrium Political Budget Cycles. American Economic Review 80: 21-36.

and Sibert, Anne 1988. Equilibrium Political Business Cycles. Review of Economic Studies 55: 1-16.

Roubini, Nouriel and Sachs, Jeffrey. 1989. Political and Economic Determinants of Budget Deficits in the Industrial Democracies. European Economic Review 33: 903-933.

Tabellini, Guido and Alesina, Alberto. 1990. Voting on the Budget Deficit. American Economic Review 80: 37-52.

Tufte, Edward. 1978. Political Control of the Economy. Princeton, N.J.: Princeton University Press. 
Table 1

Panel Regressions on GDP Growth Dependent Variable: $Y$

\begin{tabular}{ccc}
\hline Variable* & $\begin{array}{c}(1) \\
\text { Coefficient } \\
\text { (t-statistic) }\end{array}$ & $\begin{array}{c}(2) \\
\text { Coefficient } \\
\text { (t-statistic) }\end{array}$ \\
\hline Constant & -0.0001 & 0.130 \\
& $(-0.004)$ & $(0.52)$ \\
Y(-1) & 0.713 & 0.732 \\
& $(28.82)$ & $(29.49)$ \\
Y(-2) & -0.055 & -0.059 \\
YW & $(-2.34)$ & $(-2.48)$ \\
PBC4 & 0.396 & 0.344 \\
& $(13.73)$ & $(12.03)$ \\
PBC6 & -0.001 & - \\
& $(-0.64)$ & -0.110 \\
$R^{2}$ & - & $(-0.97)$ \\
\end{tabular}

* The estimated regressions include country fixed effects which are not reported in the table. 
Table 2

Panel Regressions on Unemployment

Dependent Variable: $\mathrm{U}^{\text {DIF }}$

\begin{tabular}{|c|c|c|}
\hline Variable* & $\begin{array}{c}\text { (1) } \\
\text { Coefficient } \\
\text { (t-statistic) }\end{array}$ & $\begin{array}{c}\text { (2) } \\
\text { Coefficient } \\
\text { (t-statistic) }\end{array}$ \\
\hline Constant & $\begin{array}{l}0.035 \\
(3.10)\end{array}$ & $\begin{array}{l}0.167 \\
(3.77)\end{array}$ \\
\hline $\mathrm{U}^{\mathrm{DIP}}(-1)$ & $\begin{array}{c}1.334 \\
(49.10)\end{array}$ & $\begin{array}{c}1.323 \\
(50.98)\end{array}$ \\
\hline$U^{\mathrm{DtP}}(-2)$ & $\begin{array}{c}-0.333 \\
(-12.07)\end{array}$ & $\begin{array}{c}-0.335 \\
(-12.79)\end{array}$ \\
\hline PBC4 & $\begin{array}{l}-0.003 \\
(-0.13)\end{array}$ & $\ldots$ \\
\hline PBC6 & - & $\begin{array}{l}-0.014 \\
(-0.80)\end{array}$ \\
\hline $\mathbf{R}^{2}$ & 0.99 & 0.99 \\
\hline
\end{tabular}

* The estimated regressions include country fixed effects which are not reported in the table. 
Table 3

Political Business Cycle Theory
Dependent Varlable: Y
(t-otatistics In parentheses)

\begin{tabular}{|c|c|c|c|c|c|c|c|}
\hline Country & Const & $Y_{t-1}$ & $Y_{t-2}$ & \multicolumn{2}{|c|}{$P B C(J)$} & YW & $\mathrm{R}^{2}$ \\
\hline US & $\begin{array}{r}0.247 \\
(0.83)\end{array}$ & $\begin{array}{r}1.139 \\
(12.21)\end{array}$ & $\begin{array}{r}-0.384 \\
(-4.20)\end{array}$ & $\begin{array}{r}0.334 \\
(1.22)\end{array}$ & (6) & $\begin{array}{r}0.101 \\
(1.31)\end{array}$ & 0.78 \\
\hline UK & $\begin{array}{l}-0.062 \\
(-0.16)\end{array}$ & $\begin{array}{r}0.517 \\
(5.03)\end{array}$ & $\begin{array}{r}-0.099 \\
(-1.05)\end{array}$ & $\begin{array}{r}0.737 \\
(1.72)\end{array}$ & (6) & $\begin{array}{r}0.317 \\
(3.16)\end{array}$ & 0.45 \\
\hline Austria & $\begin{array}{l}-0.392 \\
(-0.423)\end{array}$ & $\begin{array}{c}0.863 \\
(8.565)\end{array}$ & $\begin{array}{l}-0.168 \\
(-1.734)\end{array}$ & $\begin{array}{c}0.129 \\
(0.135)\end{array}$ & $(4)$ & $\begin{array}{c}0.484 \\
(2.363)\end{array}$ & 0.623 \\
\hline Denmark & $\begin{array}{c}0.112 \\
(0.323)\end{array}$ & $\begin{array}{c}0.758 \\
(7.739)\end{array}$ & $\begin{array}{l}-0.150 \\
(-1.601)\end{array}$ & $\begin{array}{l}-0.105 \\
(-0.334)\end{array}$ & (6) & $\begin{array}{c}0.330 \\
(3.739)\end{array}$ & 0.657 \\
\hline Norway & $\begin{array}{c}0.964 \\
(3.043)\end{array}$ & $\begin{array}{c}0.847 \\
(8.450)\end{array}$ & $\begin{array}{l}-0.144 \\
(-1.437)\end{array}$ & $\begin{array}{c}-0.006 \\
(-0.027)\end{array}$ & $(6)$ & $\begin{array}{c}0.086 \\
(1.602)\end{array}$ & 0.613 \\
\hline Canada & $\begin{array}{r}0.401 \\
(1.24)\end{array}$ & $\begin{array}{r}0.742 \\
(7.73)\end{array}$ & $\begin{array}{r}-0.258 \\
(-3.03)\end{array}$ & $\begin{array}{r}0.081 \\
(0.25)\end{array}$ & (6) & $\begin{array}{r}0.510 \\
(5.15)\end{array}$ & 0.72 \\
\hline Belgium & $\begin{array}{l}-1.774 \\
(-2.930)\end{array}$ & $\begin{array}{c}0.628 \\
(6.594)\end{array}$ & $\begin{array}{c}-0.073 \\
(-0.845)\end{array}$ & $\begin{array}{c}-0.287 \\
(-0.470)\end{array}$ & (4) & $\begin{array}{c}0.873 \\
(5.630)\end{array}$ & 0.690 \\
\hline Germany & $\begin{array}{r}-0.961 \\
(-2.37)\end{array}$ & $\begin{array}{r}0.463 \\
(4.58)\end{array}$ & $\begin{array}{r}0.051 \\
(0.58)\end{array}$ & $\begin{array}{r}0.905 \\
(2.56)\end{array}$ & (6) & $\begin{array}{r}0.555 \\
(5.47)\end{array}$ & 0.66 \\
\hline Italy & $\begin{array}{c}0.246 \\
(0.356)\end{array}$ & $\begin{array}{c}0.948 \\
(9.638)\end{array}$ & $\begin{array}{c}-0.238 \\
(-2.368)\end{array}$ & $\begin{array}{c}-0.100 \\
(-0.153)\end{array}$ & (4) & $\begin{array}{c}0.284 \\
(2.145)\end{array}$ & 0.646 \\
\hline Netherlands & $\begin{array}{r}-1.579 \\
(-2.95)\end{array}$ & $\begin{array}{r}0.506 \\
(4.97)\end{array}$ & $\begin{array}{r}0.159 \\
(1.71)\end{array}$ & $\begin{array}{r}-0.256 \\
(-0.51)\end{array}$ & (6) & $\begin{array}{r}0.839 \\
(6.06)\end{array}$ & 0.76 \\
\hline Australla & $\begin{array}{r}0.884 \\
(1.72)\end{array}$ & $\begin{array}{r}0.569 \\
(5.71)\end{array}$ & $\begin{array}{r}0.028 \\
(0.30)\end{array}$ & $\begin{array}{r}-0.806 \\
(-2.12)\end{array}$ & (6) & $\begin{array}{r}0.327 \\
(3.39)\end{array}$ & 0.59 \\
\hline New Zealand & $\begin{array}{r}-0.253 \\
(-0.86)\end{array}$ & $\begin{array}{r}0.790 \\
(7.74)\end{array}$ & $\begin{array}{r}-0.012 \\
(0.12)\end{array}$ & $\begin{array}{c}0.780 \\
(2.885)\end{array}$ & (4) & $\begin{array}{r}0.154 \\
(2.46)\end{array}$ & 0.76 \\
\hline Finland & $\begin{array}{r}0.194 \\
(0.23)\end{array}$ & $\begin{array}{r}0.431 \\
(3.27)\end{array}$ & $\begin{array}{r}0.205 \\
(1.53)\end{array}$ & $\begin{array}{r}1.071 \\
(1.28)\end{array}$ & (4) & $\begin{array}{r}0.240 \\
(1.50)\end{array}$ & 0.33 \\
\hline Sweden & $\begin{array}{r}0.405 \\
(0.80)\end{array}$ & $\begin{array}{r}0.528 \\
(4.10)\end{array}$ & $\begin{array}{r}0.024 \\
(0.19)\end{array}$ & $\begin{array}{r}0.660 \\
(1.22)\end{array}$ & (4) & $\begin{array}{r}0.096 \\
(0.81)\end{array}$ & 0.33 \\
\hline Ireland & $\begin{array}{r}-0.710 \\
(-0.55)\end{array}$ & $\begin{array}{r}0.588 \\
(3.58)\end{array}$ & $\begin{array}{l}-0.148 \\
(0.95)\end{array}$ & $\begin{array}{r}0.512 \\
(0.34)\end{array}$ & (4) & $\begin{array}{r}1.203 \\
(2.86)\end{array}$ & 0.60 \\
\hline France & $\begin{array}{r}0.498 \\
(0.95)\end{array}$ & $\begin{array}{r}0.317 \\
(2.80)\end{array}$ & $\begin{array}{r}0.270 \\
(2.52)\end{array}$ & $\begin{array}{r}-0.720 \\
(-1.28)\end{array}$ & & $\begin{array}{c}0.308 \\
(2.741)\end{array}$ & 0.42 \\
\hline Japan & $\begin{array}{c}0.147 \\
(0.350)\end{array}$ & $\begin{array}{c}0.835 \\
(8.297)\end{array}$ & $\begin{array}{c}0.031 \\
(0.322)\end{array}$ & $\begin{array}{c}0.627 \\
(1.775)\end{array}$ & $(6)$ & $\begin{array}{c}0.124 \\
(1.343)\end{array}$ & 0.811 \\
\hline Switzerland & $\begin{array}{c}-1.201 \\
(-2.252)\end{array}$ & $\begin{array}{c}0.614 \\
(5.062)\end{array}$ & $\begin{array}{c}0.144 \\
(1.235)\end{array}$ & $\begin{array}{c}0.501 \\
(0.788)\end{array}$ & $(4)$ & $\begin{array}{c}0.499 \\
(3.968)\end{array}$ & 0.696 \\
\hline
\end{tabular}




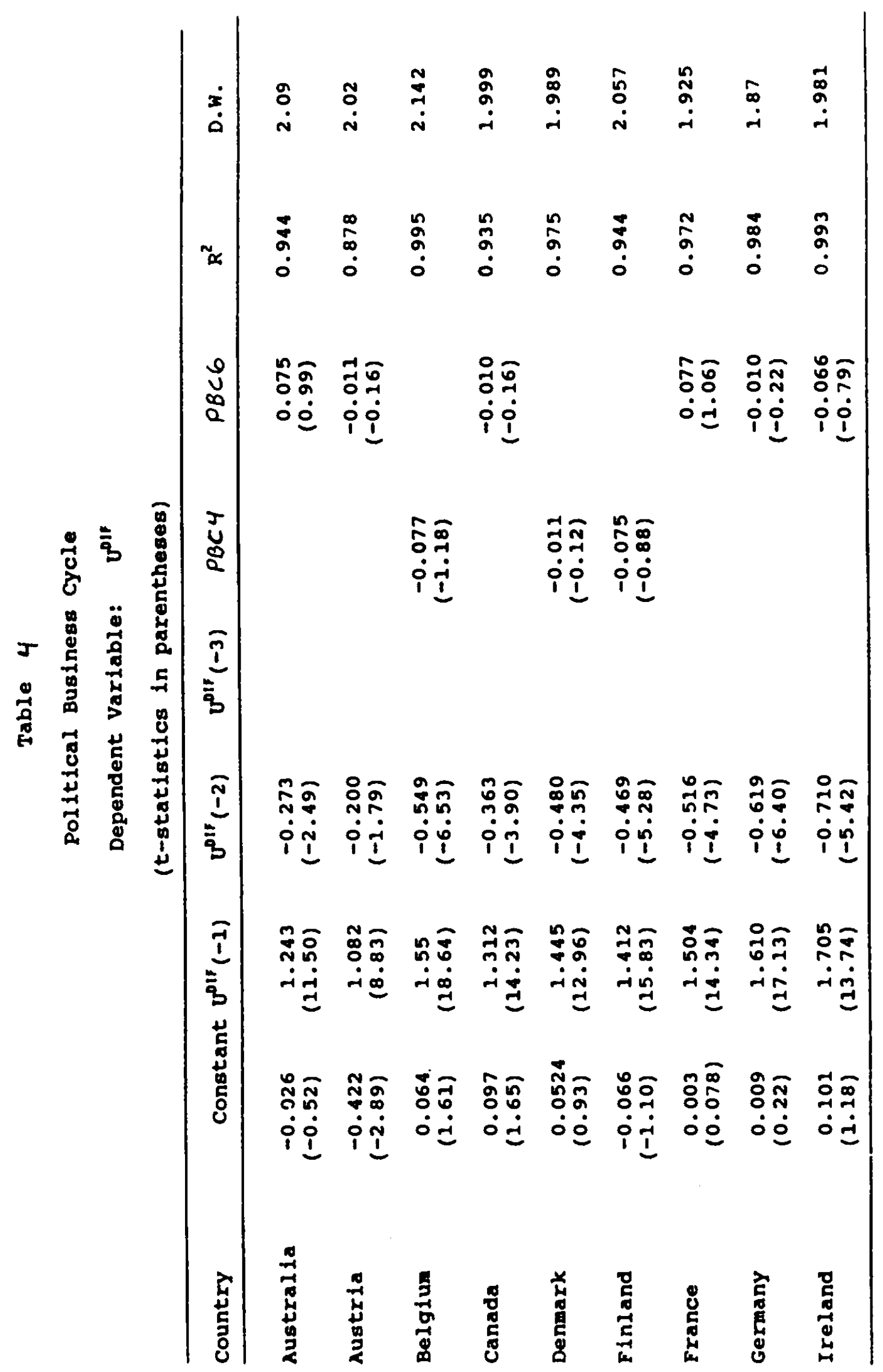




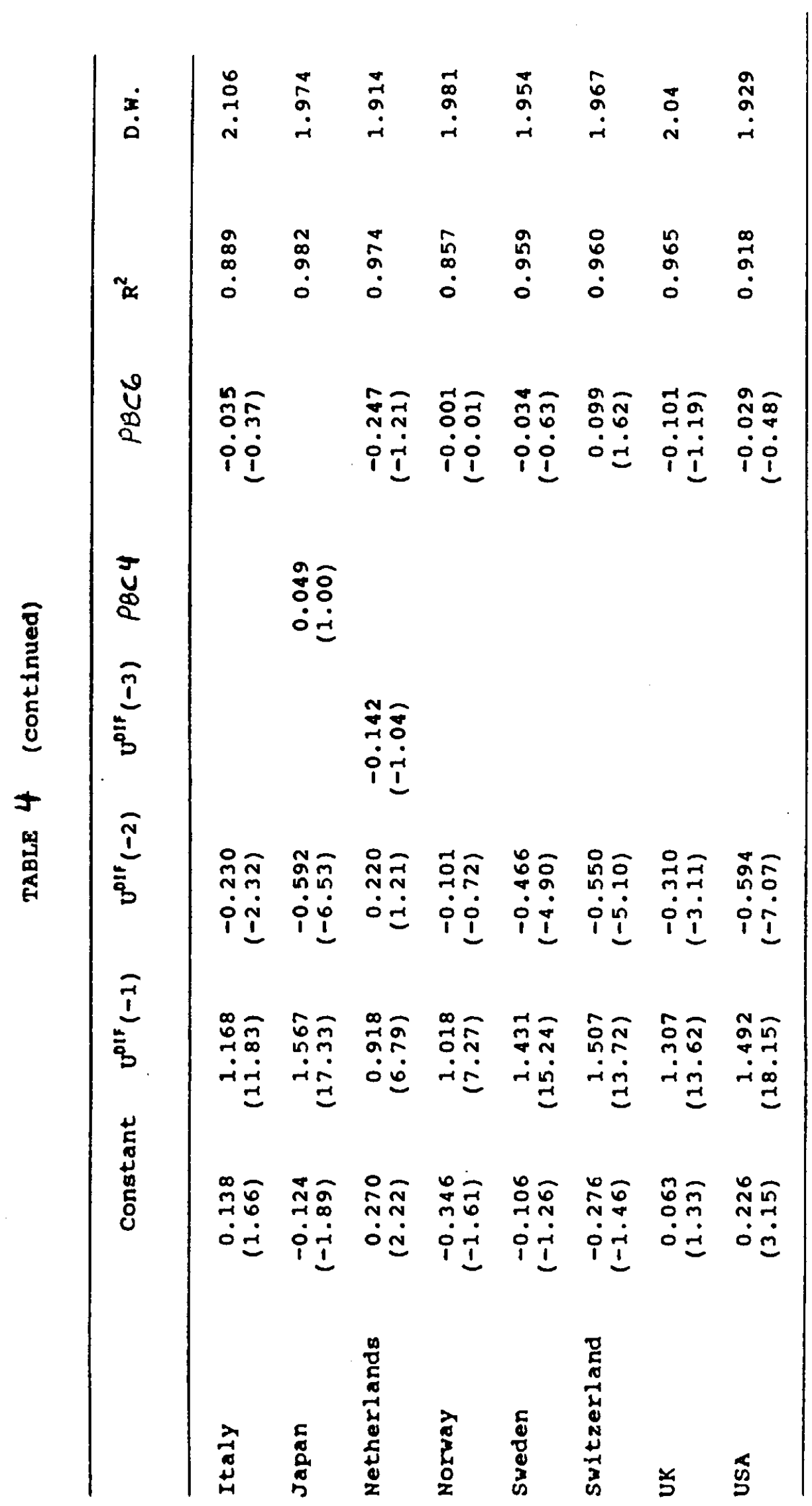


Table 5

Panel Regressions on Inflation

Dependent Variable:

\begin{tabular}{ccc}
\hline Variable* & $\begin{array}{c}(1) \\
\text { Coefficient } \\
(t-s t a t i s t i c)\end{array}$ & $\begin{array}{c}(2) \\
\text { Coefficient } \\
\text { (t-statistic) }\end{array}$ \\
\hline Constant & -0.009 & -0.129 \\
$\pi(-1)$ & $(-0.72)$ & $(-1.06)$ \\
& 1.085 & 1.078 \\
$\pi(-2)$ & $(47.06)$ & $(46.93)$ \\
$\pi(-3)$ & -0.115 & -0.114 \\
$\pi W$ & $(-3.41)$ & $(-3.40)$ \\
& -0.118 & -0.111 \\
PBCX & $(-5.43)$ & $(-5.17)$ \\
& 0.141 & 0.141 \\
& $(13.06)$ & $(13.12)$ \\
& 0.100 & - \\
$\mathrm{R}^{2}$ & $(1.76)$ & 0.263 \\
& & $(4.67)$ \\
\end{tabular}

* The estimated regressions include country fixed effects which are not reported in the table. 


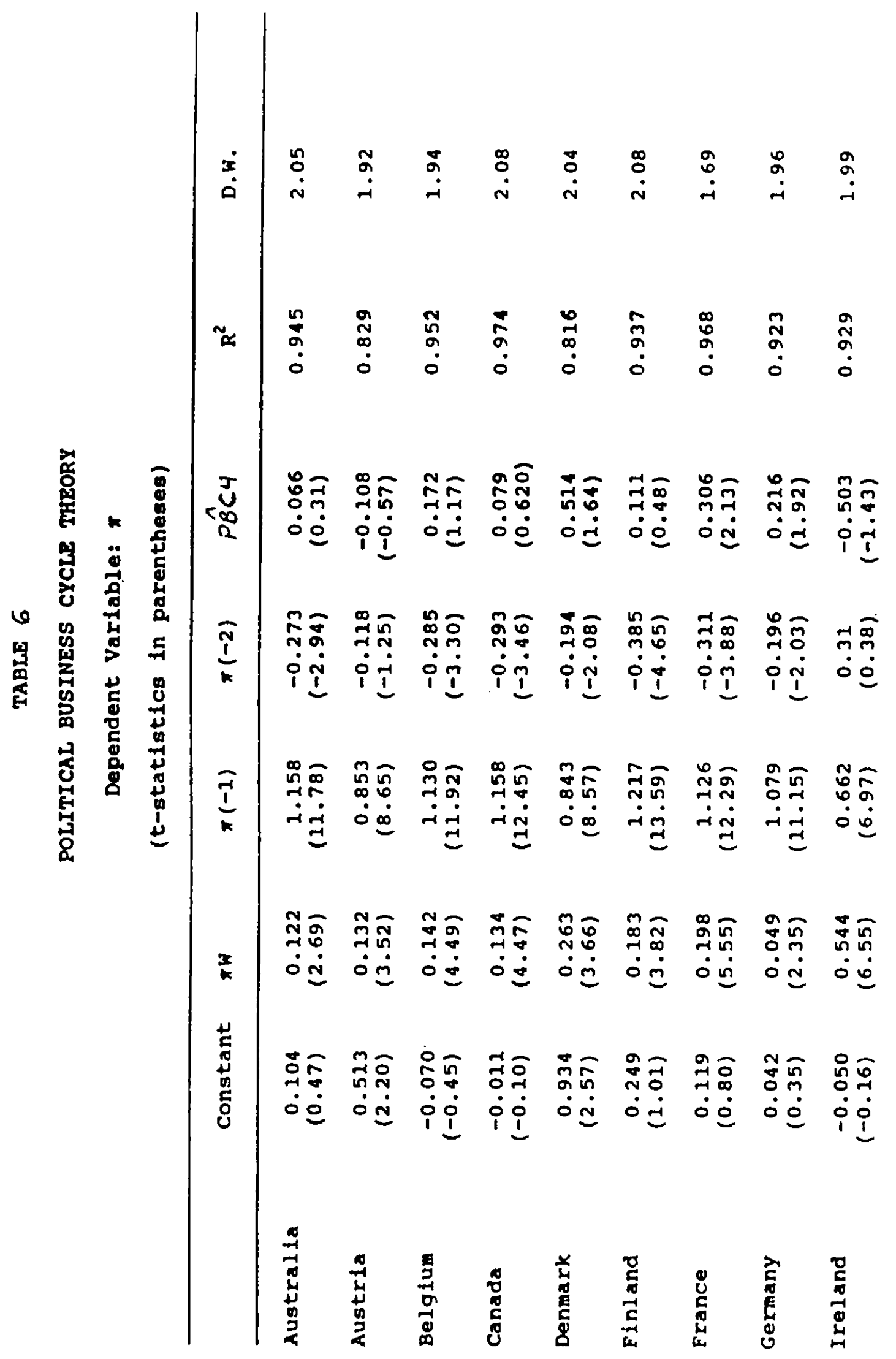




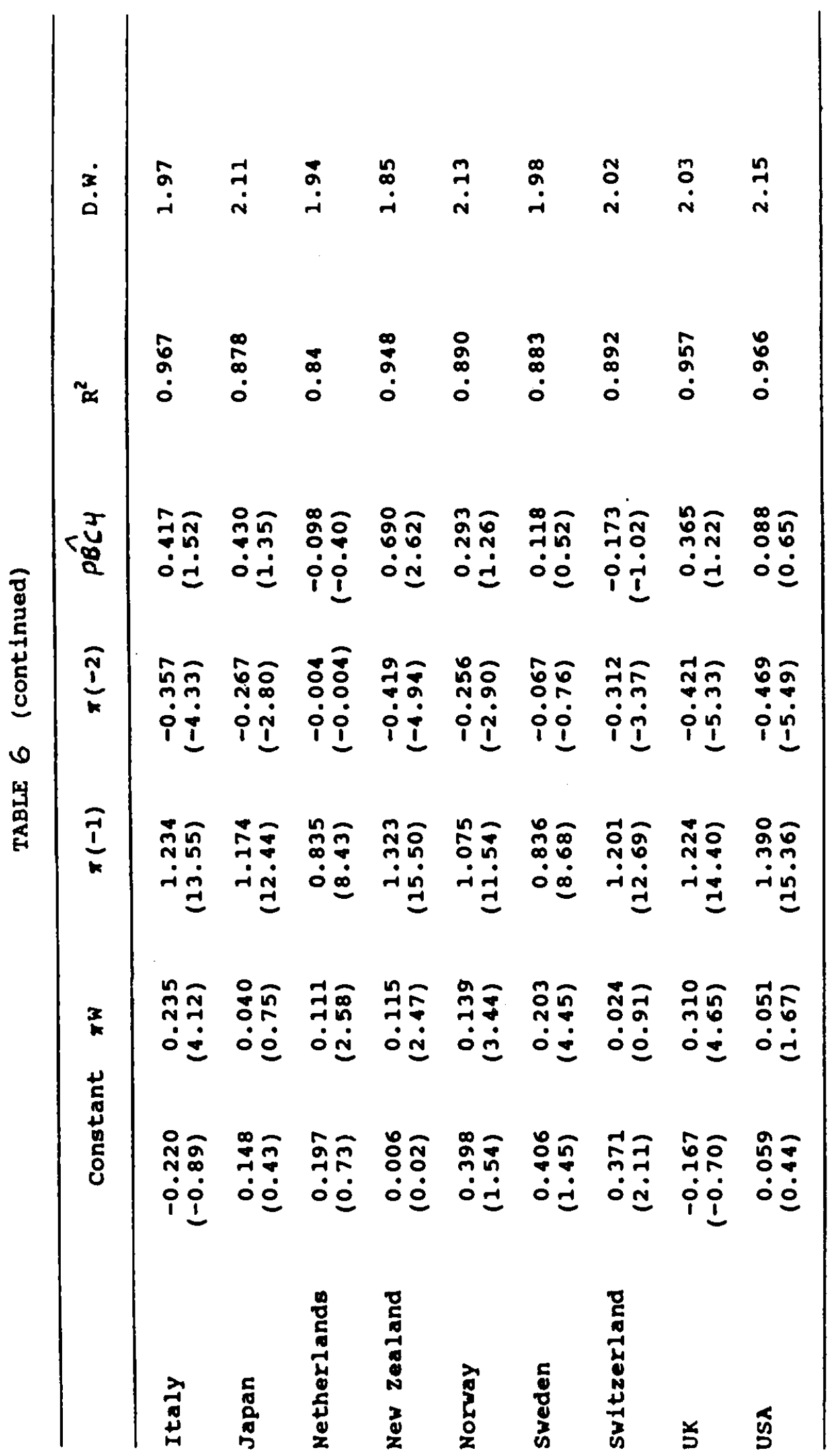


Table 7

Panel Data Money Growth

Dependent Variable: $m$

\begin{tabular}{|c|c|c|c|c|}
\hline \multirow{2}{*}{$\frac{\text { Description* }}{\text { PBC Test }}$} & \multicolumn{2}{|c|}{ No Country Dummies } & \multicolumn{2}{|c|}{ With Country Dum. } \\
\hline & $\begin{array}{l}\text { Coeff. } \\
\text { (t-stat.) }\end{array}$ & $\begin{array}{c}\mathrm{R}^{2} \\
\mathrm{~N} \text { Obs. }\end{array}$ & $\begin{array}{l}\text { Coeff. } \\
\text { (t-stat.) }\end{array}$ & $\begin{array}{c}R^{2} \\
\mathrm{~N} \text { Obs. }\end{array}$ \\
\hline PBC4 & $\begin{array}{l}0.477 \\
(2.49)\end{array}$ & $\begin{array}{l}0.73 \\
1887\end{array}$ & $\begin{array}{l}0.480 \\
(2.50)\end{array}$ & $\begin{array}{l}0.73 \\
1887\end{array}$ \\
\hline PBC6 & $\begin{array}{l}0.356 \\
(2.03)\end{array}$ & $\begin{array}{l}0.73 \\
1852 \\
\end{array}$ & $\begin{array}{l}0.355 \\
(2.01)\end{array}$ & $\begin{array}{l}0.73 \\
1852 \\
\end{array}$ \\
\hline Partisan Test & \multicolumn{2}{|c|}{$\begin{array}{l}\text { Coefficient } \\
\text { (t-statistic) }\end{array}$} & \multicolumn{2}{|c|}{$\begin{array}{l}\text { Coefficient } \\
\text { (t-statistic) }\end{array}$} \\
\hline PBC4 - Left & \multicolumn{2}{|c|}{$\begin{array}{l}0.415 \\
(1.42) \\
\end{array}$} & \multicolumn{2}{|c|}{$\begin{array}{l}0.411 \\
(1.40) \\
\end{array}$} \\
\hline PBC4 - Right & \multicolumn{2}{|c|}{$\begin{array}{l}0.527 \\
(2.09) \\
\end{array}$} & \multicolumn{2}{|c|}{$\begin{array}{l}0.531 \\
(2.09) \\
\end{array}$} \\
\hline Difference Test 4 & \multicolumn{2}{|c|}{$\begin{array}{l}-0.112 \\
(-0.29)\end{array}$} & \multicolumn{2}{|c|}{$\begin{array}{r}-0.120 \\
(-0.31) \\
\end{array}$} \\
\hline PBC6 - Left & \multicolumn{2}{|c|}{$\begin{array}{l}0.403 \\
(1.52)\end{array}$} & \multicolumn{2}{|c|}{$\begin{array}{l}0.409 \\
(1.52) \\
\end{array}$} \\
\hline PBC6 - Right & \multicolumn{2}{|c|}{$\begin{array}{l}0.323 \\
(1.39)\end{array}$} & \multicolumn{2}{|c|}{$\begin{array}{l}0.314 \\
(1.33) \\
\end{array}$} \\
\hline Difference Test6 & \multicolumn{2}{|c|}{$\begin{array}{l}0.080 \\
(0.23)\end{array}$} & \multicolumn{2}{|c|}{$\begin{array}{l}0.095 \\
(0.27)\end{array}$} \\
\hline
\end{tabular}

* The estimated regressions include lags of the dependent variable which are not reported in the table. 
Table 8

Country Money Growth PBC Test

Dependent Variable: $m$

\begin{tabular}{|c|c|c|c|c|}
\hline \multirow{2}{*}{ Country* } & \multicolumn{2}{|c|}{ PBC4 } & \multicolumn{2}{|c|}{ PBC6 } \\
\hline & $\begin{array}{l}\text { Coefficient } \\
\text { (t-statistic) }\end{array}$ & $\begin{array}{c}\mathrm{R}^{2} \\
\mathrm{~N} \text { Obs. }\end{array}$ & $\begin{array}{l}\text { Coefficient } \\
\text { (t-statistic) }\end{array}$ & $\begin{array}{c}\mathbf{R}^{2} \\
\text { N Obs. }\end{array}$ \\
\hline Australia & $\begin{array}{l}0.945 \\
(1.73) \\
\end{array}$ & $\begin{array}{l}0.87 \\
108\end{array}$ & $\begin{array}{l}0.376 \\
(0.71) \\
\end{array}$ & $\begin{array}{r}0.87 \\
106\end{array}$ \\
\hline Austria & $\begin{array}{l}-0.207 \\
(-0.36)\end{array}$ & $\begin{array}{c}0.78 \\
108\end{array}$ & $\begin{array}{l}-0.146 \\
(-0.28)\end{array}$ & $\begin{array}{c}0.79 \\
106\end{array}$ \\
\hline Belgium & $\begin{array}{l}0.104 \\
(0.22)\end{array}$ & $\begin{array}{c}0.75 \\
108\end{array}$ & $\begin{array}{l}0.153 \\
(0.35) \\
\end{array}$ & $\begin{array}{l}0.75 \\
106 \\
\end{array}$ \\
\hline Canada & $\begin{array}{l}0.563 \\
(0.39)\end{array}$ & $\begin{array}{l}0.82 \\
64\end{array}$ & $\begin{array}{l}0.571 \\
(0.45)\end{array}$ & $\begin{array}{l}0.79 \\
62\end{array}$ \\
\hline Denmark & $\begin{array}{l}-0.607 \\
(-0.67) \\
\end{array}$ & $\begin{array}{r}0.61 \\
108 \\
\end{array}$ & $\begin{array}{l}0.553 \\
(0.64) \\
\end{array}$ & $\begin{array}{c}0.62 \\
106\end{array}$ \\
\hline Finland & $\begin{array}{l}0.840 \\
(0.77)\end{array}$ & $\begin{array}{r}0.65 \\
108\end{array}$ & $\begin{array}{l}0.176 \\
(0.17) \\
\end{array}$ & $\begin{array}{r}0.67 \\
106 \\
\end{array}$ \\
\hline France & $\begin{array}{l}0.401 \\
(0.39)\end{array}$ & $\begin{array}{c}0.46 \\
108 \\
\end{array}$ & $\begin{array}{l}-0.398 \\
(-0.45)\end{array}$ & $\begin{array}{l}0.46 \\
106 \\
\end{array}$ \\
\hline Germany & $\begin{array}{l}0.596 \\
(1.46) \\
\end{array}$ & $\begin{array}{c}0.82 \\
108 \\
\end{array}$ & $\begin{array}{l}0.520 \\
(1.37) \\
\end{array}$ & $\begin{array}{r}0.83 \\
106\end{array}$ \\
\hline Ireland & $\begin{array}{l}-0.047 \\
(-0.05)\end{array}$ & $\begin{array}{r}0.71 \\
108 \\
\end{array}$ & $\begin{array}{l}0.724 \\
(0.85) \\
\end{array}$ & $\begin{array}{r}0.71 \\
106 \\
\end{array}$ \\
\hline Italy & $\begin{array}{l}0.552 \\
(1.19) \\
\end{array}$ & $\begin{array}{c}0.85 \\
108 \\
\end{array}$ & $\begin{array}{l}0.381 \\
(0.91) \\
\end{array}$ & $\begin{array}{c}0.85 \\
106 \\
\end{array}$ \\
\hline Japan & $\begin{array}{l}0.604 \\
(0.95) \\
\end{array}$ & $\begin{array}{c}0.89 \\
108\end{array}$ & $\begin{array}{l}0.647 \\
(1.06) \\
\end{array}$ & $\begin{array}{c}0.89 \\
106 \\
\end{array}$ \\
\hline $\begin{array}{l}\text { Nether- } \\
\text { lands }\end{array}$ & $\begin{array}{l}0.777 \\
(1.20) \\
\end{array}$ & $\begin{array}{l}0.75 \\
108 \\
\end{array}$ & $\begin{array}{l}-0.092 \\
(-0.16)\end{array}$ & $\begin{array}{l}0.74 \\
106 \\
\end{array}$ \\
\hline $\begin{array}{c}\text { New } \\
\text { Zealand }\end{array}$ & $\begin{array}{l}2.235 \\
(2.03)\end{array}$ & $\begin{array}{c}0.70 \\
108\end{array}$ & $\begin{array}{l}1.575 \\
(1.52)\end{array}$ & $\begin{array}{c}0.70 \\
106\end{array}$ \\
\hline Norway & $\begin{array}{l}0.226 \\
(0.26)\end{array}$ & $\begin{array}{c}0.54 \\
107\end{array}$ & $\begin{array}{l}0.425 \\
(0.57)\end{array}$ & $\begin{array}{r}0.56 \\
106\end{array}$ \\
\hline
\end{tabular}




\begin{tabular}{|c|c|c|c|c|}
\hline \multirow{2}{*}{ Country* } & \multicolumn{2}{|c|}{ PBC4 } & \multicolumn{2}{c|}{ PBC6 } \\
\cline { 2 - 5 } & $\begin{array}{c}\text { Coefficient } \\
\text { (t-statistic) }\end{array}$ & $\begin{array}{c}\mathrm{R}^{2} \\
\mathrm{~N} \mathrm{Obs.}\end{array}$ & $\begin{array}{c}\text { Coefficient } \\
\text { (t-statistic) }\end{array}$ & $\begin{array}{c}\mathrm{R}^{2} \\
\text { N Obs. }\end{array}$ \\
\hline Sweden & 1.825 & 0.64 & 0.823 & 0.64 \\
& $(1.13)$ & 96 & $(0.53)$ & 94 \\
\hline Switzer- & -0.034 & 0.73 & 0.578 & 0.74 \\
land & $(-0.04)$ & 108 & $(0.71)$ & 106 \\
\hline United & -0.156 & 0.85 & -0.500 & 0.84 \\
Kingdom & $(-0.22)$ & 108 & $(-0.79)$ & 106 \\
\hline United & 0.144 & 0.87 & -0.109 & 0.85 \\
States & $(0.53)$ & 108 & $(-0.47)$ & 106 \\
\hline
\end{tabular}

* The estimated regressions include lags of the dependent variable which are not reported in the table. 
Table 9

Country Money Growth Partisan Test

Dependent Variable: $m$

\begin{tabular}{|c|c|c|c|}
\hline \multirow{2}{*}{ Country* } & PBC4 - Left & PBC4 - Right & Diff. Test4 \\
\hline & $\begin{array}{l}\text { Coefficient } \\
\text { (t-statistic) }\end{array}$ & $\begin{array}{l}\text { Coefficient } \\
\text { (t-statistic) }\end{array}$ & $\begin{array}{l}\text { Coefficient } \\
\text { (t-statistic) }\end{array}$ \\
\hline Australia & $\begin{array}{l}1.448 \\
(1.00)\end{array}$ & $\begin{array}{l}1.073 \\
(1.82) \\
\end{array}$ & $\begin{array}{l}0.375 \\
(0.25)\end{array}$ \\
\hline Austria & $\begin{array}{l}-1.223 \\
(-1.50) \\
\end{array}$ & $\begin{array}{l}0.914 \\
(1.05) \\
\end{array}$ & $\begin{array}{l}-2.137 \\
(-1.75) \\
\end{array}$ \\
\hline Belgium & $\begin{array}{l}0.285 \\
(0.27)\end{array}$ & $\begin{array}{l}-0.013 \\
(-0.02)\end{array}$ & $\begin{array}{l}0.298 \\
(0.21)\end{array}$ \\
\hline Denmark & $\begin{array}{l}-0.702 \\
(-0.63)\end{array}$ & $\begin{array}{l}-0.269 \\
(-0.16)\end{array}$ & $\begin{array}{c}-0.432 \\
(-0.21)\end{array}$ \\
\hline Finland & $\begin{array}{l}1.684 \\
(1.33)\end{array}$ & $\begin{array}{l}-1.365 \\
(-0.65)\end{array}$ & $\begin{array}{l}3.048 \\
(1.23)\end{array}$ \\
\hline France & $\begin{array}{l}-2.161 \\
(-0.83) \\
\end{array}$ & $\begin{array}{l}0.997 \\
(0.85) \\
\end{array}$ & $\begin{array}{l}-3.158 \\
(-1.07) \\
\end{array}$ \\
\hline Germany & $\begin{array}{l}0.379 \\
(0.67)\end{array}$ & $\begin{array}{l}0.872 \\
(1.42)\end{array}$ & $\begin{array}{l}-0.493 \\
(-0.61)\end{array}$ \\
\hline Ireland & $\begin{array}{l}-0.625 \\
(-0.37)\end{array}$ & $\begin{array}{l}0.178 \\
(0.16)\end{array}$ & $\begin{array}{l}-0.803 \\
(-0.40)\end{array}$ \\
\hline Italy & $\begin{array}{l}0.240 \\
(0.47)\end{array}$ & $\begin{array}{l}1.802 \\
(1.63) \\
\end{array}$ & $\begin{array}{l}-1.562 \\
(-1.29) \\
\end{array}$ \\
\hline $\begin{array}{l}\text { Nether- } \\
\text { lands }\end{array}$ & $\begin{array}{l}1.961 \\
(1.57) \\
\end{array}$ & $\begin{array}{l}0.242 \\
(0.30) \\
\end{array}$ & $\begin{array}{l}1.718 \\
(1.12) \\
\end{array}$ \\
\hline $\begin{array}{c}\text { New } \\
\text { Zealand }\end{array}$ & $\begin{array}{r}-2.338 \\
(-0.88) \\
\end{array}$ & $\begin{array}{l}3.080 \\
(2.69) \\
\end{array}$ & $\begin{array}{l}-5.418 \\
(-1.93) \\
\end{array}$ \\
\hline Norway & $\begin{array}{l}-1.289 \\
(-1.14)\end{array}$ & $\begin{array}{l}2.668 \\
(1.89)\end{array}$ & $\begin{array}{l}-3.957 \\
(-2.09)\end{array}$ \\
\hline Sweden & $\begin{array}{l}3.139 \\
(1.61)\end{array}$ & $\begin{array}{l}-1.437 \\
(-0.47) \\
\end{array}$ & $\begin{array}{l}4.576 \\
(1.24) \\
\end{array}$ \\
\hline $\begin{array}{l}\text { United } \\
\text { Kingdom }\end{array}$ & $\begin{array}{l}-0.052 \\
(-0.04)\end{array}$ & $\begin{array}{l}-0.220 \\
(-0.24)\end{array}$ & $\begin{array}{l}0.168 \\
(0.12)\end{array}$ \\
\hline
\end{tabular}




\begin{tabular}{|c|c|c|c|}
\hline \multirow{2}{*}{ Country* } & PBC4 - Left & PBC4 - Right & Diff. Test4 \\
\cline { 2 - 4 } & $\begin{array}{c}\text { Coefficient } \\
\text { (t-statistic) }\end{array}$ & $\begin{array}{c}\text { Coefficient } \\
\text { (t-statistic) }\end{array}$ & $\begin{array}{c}\text { Coefficient } \\
\text { (t-statistic) }\end{array}$ \\
\hline United & -0.097 & 0.393 & -0.490 \\
States & $(-0.24)$ & $(0.96)$ & $(-0.82)$ \\
\hline
\end{tabular}

* The estimated regressions include lags of the depedent variable which are not reported in the table. 
Tahle 10

Panel Data Regression of Deficit with Political Variahles Dependent Variable: DBY

\begin{tabular}{|c|c|c|c|c|c|}
\hline Regressors: & $\begin{array}{l}\text { Equation } \\
\text { (1) }\end{array}$ & $\begin{array}{l}\text { Equation } \\
\text { (2) }\end{array}$ & $\begin{array}{c}\text { Equation } \\
\text { (3) }\end{array}$ & $\begin{array}{c}\text { Equation } \\
(4)\end{array}$ & $\begin{array}{c}\text { Equation } \\
\text { (5) }\end{array}$ \\
\hline Constant & $\begin{array}{r}-0.002 \\
(-1.19)\end{array}$ & $\begin{array}{l}-0.006 \\
(-2.73)\end{array}$ & $\begin{array}{r}-0.007 \\
(-3.28)\end{array}$ & $\begin{array}{r}-0.004 \\
(-1.97)\end{array}$ & $\begin{array}{l}-0.0037 \\
(-1.98)\end{array}$ \\
\hline DBYL & $\begin{array}{r}0.74 \\
(17.0)\end{array}$ & $\begin{array}{r}0.71 \\
(16.0)\end{array}$ & $\begin{array}{r}0.72 \\
(16.2)\end{array}$ & $\begin{array}{r}0.74 \\
(17.2)\end{array}$ & $\begin{array}{r}0.70 \\
(14.0)\end{array}$ \\
\hline DUB & $\begin{array}{l}0.23 \\
(2.98)\end{array}$ & $\begin{array}{c}0.18 \\
(2.32)\end{array}$ & $\begin{array}{c}0.19 \\
(2.51)\end{array}$ & $\begin{array}{c}0.24 \\
(3.15)\end{array}$ & $\begin{array}{c}0.24 \\
(3.17)\end{array}$ \\
\hline DRB & $\begin{array}{c}0.56 \\
(2.66)\end{array}$ & $\begin{array}{c}0.61 \\
(2.91)\end{array}$ & $\begin{array}{c}0.56 \\
(2.71)\end{array}$ & $\begin{array}{c}0.51 \\
(2.46)\end{array}$ & $\begin{array}{c}0.50 \\
(2.38)\end{array}$ \\
\hline DGR & $\begin{array}{c}-0.47 \\
(-8.49)\end{array}$ & $\begin{array}{c}-0.45 \\
(-8.31)\end{array}$ & $\begin{array}{c}-0.46 \\
(-8.50)\end{array}$ & $\begin{array}{c}-0.48 \\
(-8.69)\end{array}$ & $\begin{array}{c}-0.47 \\
(-8.49)\end{array}$ \\
\hline DUJAP* & $\begin{array}{c}1.82 \\
(1.46)\end{array}$ & $\begin{array}{c}2.75 \\
(2.16)\end{array}$ & $\begin{array}{c}2.62 \\
(2.07)\end{array}$ & $\begin{array}{l}1.76 \\
(1.42)\end{array}$ & $\begin{array}{c}1.70 \\
(1.38)\end{array}$ \\
\hline ELE & - & - & $\begin{array}{l}0.0065 \\
(2.17)\end{array}$ & $\begin{array}{l}0.0072 \\
(2.41)\end{array}$ & $\begin{array}{l}0.0063 \\
(2.04)\end{array}$ \\
\hline POL & - & $\begin{array}{l}0.0042 \\
(2.77)\end{array}$ & $\begin{array}{l}0.0039 \\
(2.57)\end{array}$ & - & - \\
\hline DBYLELE & - & - & - & - & $\begin{array}{c}0.13 \\
(1.55)\end{array}$ \\
\hline $\mathbf{R}^{2}$ & 0.65 & 0.66 & 0.67 & 0.66 & 0.66 \\
\hline
\end{tabular}

t-statistics in parentheses

* The regressor DUJAP is a country specific dummy for DUB for Japan. This is the only country for which a country specific effect was found in the data: its positive estimate implies that an increase in Japanese unemployment has a much stronger effect on budget deficits than in any other countries. The results, however, do not depend in any way on the inclusion of this variable. 
Table $A \cdot 1$

Election and Regime Change

E - Election; CH L - Change Left; Ch R - Change RIght

AUSTRALIA: Endogenous TIning, 3 YRS AUSTRIA: Endogenous T1ming, 4 YRS

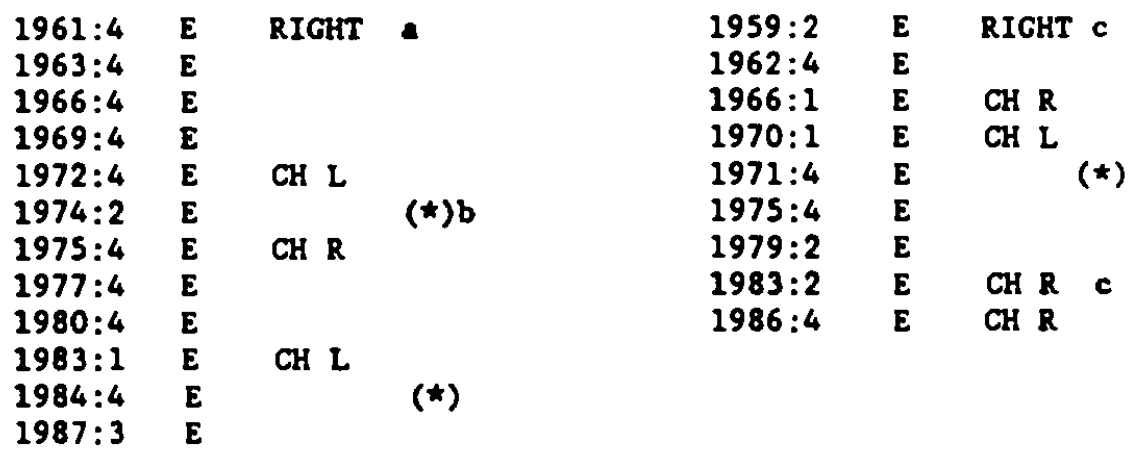

BELGIUM: Endogenous TImIng, 4 YRS

CANADA: Endogenous IIming, 5 YRS

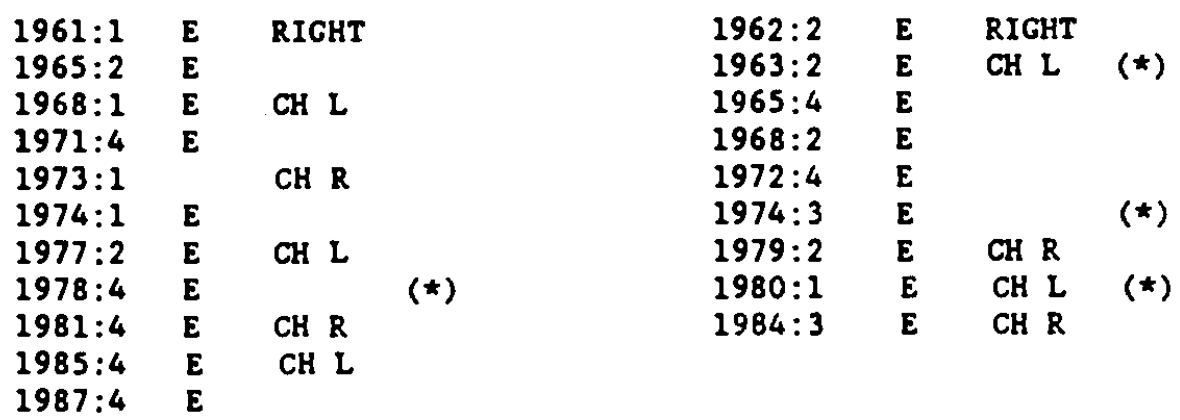

DENMARK: Endogenous TIming, 4 YRS FINLAND: Endogenous TIming, 4 YRS

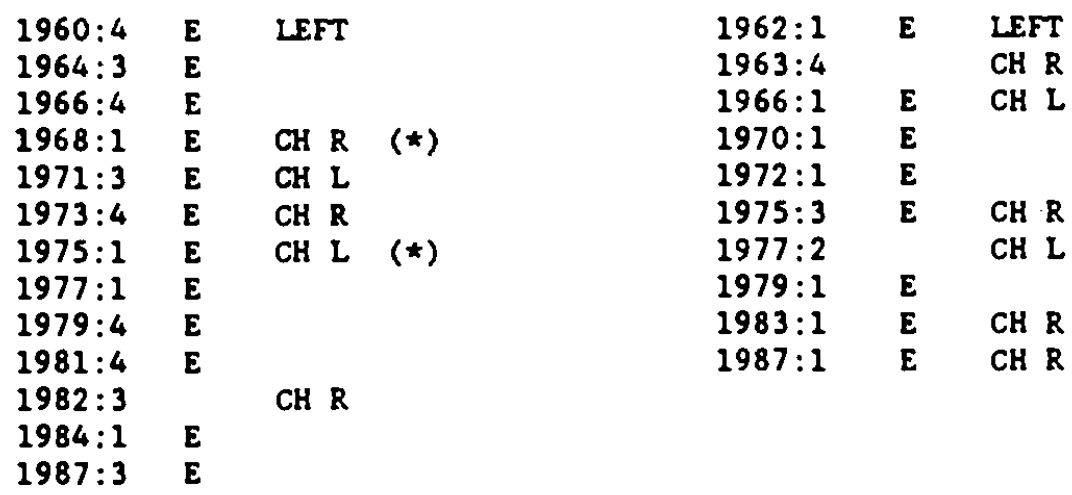


Table A-1 (continued)

FRaNCE: Endogenous TIming, 5 YRS

GERMANY: Endogenous TImIng, 4 YRS

$\begin{array}{lll}1962: 4 & \text { E } & \text { RIGHT } \\ 1967: 1 & \text { E } & \\ 1968: 2 & \text { E } & \\ 1973: 1 & \text { E } & \\ 1978: 1 & \text { E } & \\ 1981: 2 & \text { E } & \text { CH L } \\ 1984: 3 & & \text { CH R } \\ 1986: 1 & \text { E } & \text { CH R }\end{array}$

$\begin{array}{llll}1961: 3 & \text { E } & \text { RIGHT } \\ 1965: 3 & \text { E } & & \\ 1966: 4 & & \text { CH L } & \text { C } \\ 1969: 3 & \text { E } & \text { CH L } & \\ 1972: 4 & \text { E } & \text { CH R } & \\ 1976: 4 & \text { E } & & \\ 1980: 4 & \text { E } & & \\ 1982: 4 & & \text { CH R } \\ 1983: 1 & \text { E } & & \\ 1987: 1 & \text { E } & & \end{array}$

IRELAND: Endogenous TIming, 5 YRS

ITALY: Endogenous TIning, 5 YRS

$\begin{array}{llll}1961: 4 & \text { E } & \text { RIGHT } & \\ 1965: 2 & \text { E } & & \\ 1969: 2 & \text { E } & & \\ 1973: 1 & \text { E } & \text { CH I } & \\ 1977: 2 & \text { E } & \text { CH R } & \\ 1981: 2 & \text { E } & \text { CH L } & \\ 1982: 1 & \text { E } & \text { CH R } & (*) \\ 1982: 4 & \text { E } & \text { CH L } & (*) \\ 1987: 1 & \text { E } & & \end{array}$

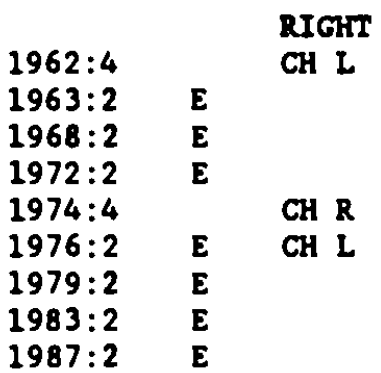

JAPAN: Endogenous Timing, 4 IRS

NETHERLANDS: Endogenous TIming, 4 YRS

$\begin{array}{lll}1960: 4 & \text { E } & \text { RIGHT } \\ 1963: 4 & \text { E } & \\ 1967: 1 & \text { E } & \\ 1969: 4 & \text { E } & \\ 1972: 4 & \text { E } & \\ 1976: 4 & \text { E } & \\ 1979: 4 & \text { E } & \\ 1980: 2 & \text { E } & \\ 1983: 4 & \text { E } & \\ 1986: 3 & \text { E } & \end{array}$

$\begin{array}{llll}1959: 1 & \text { E } & \text { RIGHT } & \\ 1963: 2 & \text { E } & & \\ 1965: 2 & & \text { CH L } & \\ 1967: 1 & \text { E } & \text { CH R } & \\ 1971: 1 & \text { E } & & \\ 1972: 4 & \text { E } & & \text { (*) } \\ 1973: 2 & & \text { CH L } & \\ 1977: 2 & \text { E } & & \\ 1977: 4 & & \text { CH R } & \\ 1981: 2 & \text { E } & \text { CH L } & \\ 1982: 3 & \text { E } & \text { CH R } & \text { (*) } \\ 1986: 2 & \text { E } & & \end{array}$


Table A-1 (continued)

NEW 2EALAND: Endogenous TIming, 3 YRS NORWAY: Exogenous IIming, 4 YRS

$\begin{array}{llllll}1960: 4 & \text { E } & \text { RIGHT } & 1961: 3 & \text { E } & \text { LEFT } \\ 1963: 4 & \text { E } & & 1965: 3 & \text { E } & \text { CH R } \\ 1966: 4 & \text { E } & & 1969: 3 & \text { E } & \\ 1969: 4 & \text { E } & & 1971: 4 & & \text { CH L } \\ 1972: 4 & \text { E } & \text { CH L } & 1972: 4 & & \text { CH R } \\ 1975: 4 & \text { E } & \text { CH R } & 1973: 3 & \text { E } & \text { CH L } \\ 1978: 4 & \text { E } & & 1977: 3 & \text { E } & \\ 1981: 4 & \text { E } & & 1981: 3 & \text { E } & \text { CH R } \\ 1984: 3 & \text { E } & \text { CH L } & 1985: 3 & \text { E } & \\ 1987: 3 & \text { E } & & 1986: 2 & & \text { CH L }\end{array}$

SWEDEN: Exogenous TIming, 3 YRS since late 608 , constitutional reform

$\begin{array}{llllll}1960: 3 & \text { E } & \text { LEFT } & 1959: 4 & \text { E } & \text { RICKT } \\ 1964: 3 & \text { E } & & 1963: 4 & \text { E } & \\ 1968: 3 & \text { E } & & 1967: 4 & \text { E } & \\ 1970: 3 & \text { E } & & 1971: 4 & \text { E } \\ 1973: 3 & \text { E } & & 1975: 4 & \text { E } \\ 1976: 3 & \text { E } & \text { CH R } & 1979: 4 & \text { E } \\ 1979: 3 & \text { E } & & 1983: 4 & \text { E } \\ 1982: 3 & \text { E } & \text { CH L } & 1987: 4 & \text { E } \\ 1985: 3 & \text { E } & & & & \end{array}$

UK: Endogenous Timing, 5 YRS

$\begin{array}{llll}1959: 4 & \text { E } & \text { RIGHT } & \\ 1964: 4 & \text { E } & \text { CH L } & \\ 1966: 1 & \text { E } & & \text { (*) } \\ 1970: 2 & \text { E } & \text { CH R } & \\ 1974: 1 & \text { E } & & \\ 1974: 3 & \text { E } & \text { CH L } & (*) \\ 1979: 2 & \text { E } & \text { CH R } & \\ 1983: 2 & \text { E } & & \\ 1987: 2 & \text { E } & & \end{array}$

SWIT2ERLAND: ExOgenous TImIng, 4 YRS

USA: Exogenous Timing, 4 YRS RIGHT

1960:4 E CH L

1964:4 E

1968:4 E CH R

$\begin{array}{lll}1972: 4 & E & \\ 1976.4 & E & C H ~\end{array}$

$\begin{array}{lll}1976: 4 & E & \mathrm{CH} \mathrm{L} \\ 1980: 4 & \mathrm{E} & \mathrm{CH} \mathrm{R}\end{array}$

a RIGHT or LEFT Indicates the type of government in power at the beginning of the sample which is 1959:1. We also Indicate for each country whether elections dates are endogenous or exogenous and the offlctal number of years between two elections.

b Elections denoted with an asterisk "*n are not included in tests of the political business cycle theory because they are too close (less than two years) to previous elections. They are however included in tests of the opportunistic endogenous election model.

c Both Germany and Austria had grand coalitions of Left and Right parties. Thus, finer administration varlable was used in the RPT inflation and partisan (Hibbs) regressions. This also explains the occurence of a rightward shift from an already central Right leaning party. 
Table A- 1 (continued)

Source: Election Dates are obtained from Banks (1989); dates of changes of government and their classification of "Right" and "Left" are obtalned from Alt (1985) and Banks (1989). 